\title{
THE USEFULNESS OF CASE STUDIES IN DEVELOPING CORE COMPETENCIES IN A PROFESSIONAL ACCOUNTING PROGRAMME: A NEW ZEALAND STUDY
}

\author{
Sidney Weil * \\ Peter Oyelere ** \\ Elizabeth Rainsbury ***
}

\author{
August 2002 \\ Centre of Accounting Education and Research \\ PO Box 84 \\ Lincoln University \\ CANTERBURY \\ Telephone No: (64) (3) 3253627 \\ Fax No: (64) (3) 3253847 \\ E-mail: weils@lincoln.ac.nz \\ ISSN 1175-9127 \\ ISBN 1-877325-00-7
}




\section{First drafét}

This paper is being developed for submission to a scholarly journal; please do not quote without permission from the authors.

* Corresponding Author. Senior Lecturer, Centre of Accounting Education and Research, Commerce Division, Lincoln University, PO Box 84, Canterbury, New Zealand. Tel: +64 (3) 325 3627; Fax: +64 (3) 3253847 Email: weils@lincoln.ac.nz

** Senior Lecturer, Centre of Accounting Education and Research, Commerce Division, Lincoln University, PO Box 84 , Canterbury, New Zealand.

Tel: +64(3) 325 3627; Fax: +64 (3) 3253847 Email: oyelerep@lincoln.ac.nz

*** Lecturer, Department of Accountancy, Law and Finance, UNITEC, Private Bag 92025 , Auckland, New Zealand.

Tel: +64 (9) 849 4180; Fax: +64 (9) 8152904 Email: erainsbury@unitec.ac.nz 


\begin{abstract}
Professional accounting education in recent years has emphasised the need for competency development. One of the pedagogical techniques recommended to enhance competency development, is the use of case studies. Although case studies are being used increasingly in accounting education, research into the usefulness or effectiveness of the method is limited. This study examines students' perceptions of the use of case studies and the potential influences of certain variables, such as age, gender and first language, on such perceptions. The questionnaire-based study was conducted in the professional accounting programme of the Institute of Chartered Accountants of New Zealand (ICANZ). Analysis of the results reveals significant differences in students' perceptions of the benefits of using case studies. Gender and language-based differences in perception were also found. The results of the study provide the ICANZ with feedback on the Professional Accounting School (PAS) programme and facilitate the further development of the programme. Other professional accounting bodies may consider replicating this study using data collected on similar programmes. The results of such studies may then be compared to enhance the existing literature on competency development in professional accounting education.
\end{abstract}

Keywords: case studies; student perceptions; competencies; skills; knowledge; language; gender; professional accounting programme. 


\section{Acknowledgements}

The authors wish to thank Associate Professor Trevor Wegner, of the University of Cape Town, for his assistance with the design of the research questionnaire. Thanks are also due to Fareeha Shareef for her research assistance. 


\section{Introduction}

A significant increase in the use of case studies as a pedagogical technique in accounting education has been evident in recent years. Used primarily to develop certain thinking skills and knowledge in students, case studies are considered to be particularly valuable for simulating real-life practical problems and situations, enabling students to develop and/or improve upon a range of skills required for day-to-day business decisions.

Coinciding with the increasing use of case studies in accounting education, the last fifteen years have given rise to increasing debates about the type and levels of competencies required for entry to the accounting profession. While most of these debates originated in the United States of America (USA) (AAA 1986; Perspectives 1989; AECC 1990; AICPA 1999; IFAC 1998; IFAC 2001), similar discussions and reviews have also taken place in New Zealand and Australia (Marrian and Lothian 1992; Birkett 1993). As a consequence of this review process, a new method of examining and admitting prospective chartered accountants to the profession in New Zealand was instituted in 1998. Known as the Professional Accounting School/Professional Competence Examination 2 (PAS/PCE 2), the programme was designed to infuse candidates with certain core competencies, identified as essential for practising chartered accountants. This paper describes the background to, and provides an overview of the development of, the PAS/PCE2 programme and, in particular, measures candidates' perceptions of the usefulness of case studies in the PAS programme.

Several studies have documented the use of case studies in accounting education and identified a broad range of skills and abilities that could be imparted, developed or improved through the use of case studies (Gobeil and Phillips, 2001; Bonner, 1999; Hassall, Lewis and Broadbent, 1998; Saudagaran, 1996; Knechel, 1992; Campbell and Lewis, 1991). Little, however, has been done to investigate and report on the relative usefulness of case studies in meeting the needs of the principal stakeholders - students. This study is aimed at measuring students' perceptions of the relative usefulness of the case method as a tool for developing a set of core competencies in students. In particular, the study measures, and reports on candidates' perceptions about the perceived development of their competencies by the use of case studies in the PAS component of the PAS/PCE 2 programme of the Institute of Chartered Accountants of New Zealand (ICANZ). 
Data for the study were collected by means of a questionnaire administered to candidates at the conclusion of the PAS programme. Data were analysed to determine the greatest benefits derived from the use of case studies, as ranked by the students. Nonparametric statistical tests were used to isolate possible differentials in the ranking of the benefits of case studies in developing and imparting individual and sub-scaled competencies. Cross-gender, age, language and work experience-related statistical analyses were also conducted. The results of the analyses show that students perceive the major benefit of the use of case studies to be in improving their ability to evaluate situations from more than one perspective and to consider alternative solutions to problems. Cross-gender, age-based and first-language differences in student perceptions were also found. The findings of the study can assist those involved in post-graduate professional accounting development in New Zealand - particularly with respect to the ongoing development of the PAS programme - and in other countries. Furthermore, the findings can be of use to other institutions wishing to implement competency-based development and assessment as part of their accounting admission requirements.

The rest of the paper is organised as follows. Relevant literature on the subject is reviewed next. This is followed by a presentation of the research design and methodology. The results of the study are then reported and discussed, followed by a summary and conclusion. Suggestions for further research are presented in the final section.

\section{Literature Review}

This section provides a review of the literature relating to the use of case studies in accounting education, discusses the increasing trend towards competency-based professional accounting education and provides the background to the development of the Professional Accounting School in New Zealand.

\subsection{The Use of Case Studies}

Case studies have been widely used in education ${ }^{1}$ for many years. Their use has been particularly extensive in management education (Shapiro, 1984; Fulmer, 1992; Wines et al.,

\footnotetext{
${ }^{1}$ For examples of case-based learning in the medical field, see Schwartz and Heath (1994) and Johnstone and Biggs (1998). The use of cases is also well established in legal education (Bonk and Smith, 1998).
} 
1994). Numerous definitions of case studies are found in the management education literature (Easton ${ }^{2}$, 1992; Shapiro, 1984). Similar definitions are found in the accounting education literature. Wines, Carnegie, Boyce and Gibson (1994) describe case studies as typically possessing several features, such as issues, the consideration of which require the use of judgement and analytical reasoning skills; the inclusion of real or realistic situations, requiring a consideration of the complexity and ambiguity of the business world; and the existence of more than one possible solution to the case problem. Common to the numerous definitions of case studies are the development of problem-solving skills and the use of either real or realistic contexts.

The use of case studies in accounting education is more recent than in management education. It is, in part, a response to the call by the Accounting Education Change Commission (AECC, 1990) for more innovative teaching of accounting to achieve certain employment-related skills (Perspectives on Education, 1989), such as communication skills, intellectual skills, interpersonal skills, general knowledge, business knowledge, accounting knowledge and attitudes. Intellectual outcomes specified are to locate and organise information, to identify and solve unstructured problems and to exercise judgement. The AECC recommends the use of teaching techniques such as the case method (the use of case studies) to develop such intellectual skills.

Despite the call for the greater use of case studies in accounting education, only a few studies have examined the usefulness of case studies, with most of the literature being descriptive in nature. Literature on the nature of case studies, including their form and length, mode, extent of incorporation of actual business situations, level of detail, analytical approach, and how to incorporate the case method into accounting instruction, are summarised in Weil, Oyelere, Yeoh and Firer (2001). Irrespective of the types of case studies used, the development of skills is propounded to be their main benefit (Campbell and Lewis, 1991; Kimmel, 1995). The skills most frequently mentioned as being developed by case studies are analytical and judgement skills (Campbell and Lewis, 1991). They argue that the success or failure of the use of cases depends primarily on the specific educational objectives ascribed to their usage. For example, cases might be appropriate if the course objective is to facilitate the development of analytical and judgement skills, whereas lectures and reading assignments may, but need not exclusively, be more appropriate means of presenting basic accounting

\footnotetext{
${ }^{2}$ Easton (1992) defines a case study as a, "[means] to provide practice in problem solving and decision making in a simulated situation... The case method is primarily a vehicle for developing skills; skills which are a vital part of a decision maker's armoury ....".
} 
techniques. Bonner (1999), in presenting a comprehensive framework for choosing teaching methods based on specific learning objectives, specifies the use of cases as being one of a wide variety of teaching methods available to accounting instructors, to be used in conjunction with each other. Bonner (1999) regards cases as being particularly suitable for the development of complex cognitive skills.

Hassall et al. (1998) specify the aim of using case studies as being "to develop and apply an integrated approach to problem solving and to provide students with an understanding of the problems inherent in the application of discipline based knowledge to practical situations in a period of change" (p. 326). Similarly to Hassal et al. (1998), Wines et al. (1994) identify both cognitive (such as organisation and comprehension, judgement and analytical reasoning) and affective (such as interpersonal skills) benefits to be derived from the use of case studies.

Johnstone and Biggs (1998) identify several ways in which cases can be used in problembased learning. They view realistic cases as a means of enabling students to practise gathering relevant professional information and integrating that information within the context of the case, as well as being useful for encouraging the development of diagnostic reasoning skills.

According to Kimmel (1995), the extent to which an instructor wishes to develop particular skills in students will determine which particular type of three categories of cases - basic, intermediate, or advanced - will be used in a given situation. Thus, an instructor wishing to develop students' ability to modify judgments would use an advanced case, whereas an instructor wishing to improve students' ability to use precise terms - a lower-order thinking skill than modifying judgments - might use a basic case.

Empirical research on the use of case studies in accounting education is limited. Saudagaran (1996), using cases, inter alia, to de-emphasise a single solution approach and to stress the need to deal with uncertainty in accounting, reports that students in his study indicate that the new course improves their perception of accounting. Another perception-based study, Friedlan (1995), reports that the teaching approach - inter alia, the use of minicases - in a non-traditional course had a significant effect on students' perceptions about the skills and abilities required for academic and professional success that were more consistent with those

\footnotetext{
${ }^{3}$ To achieve this aim, Hassall $e t$ al. identify several objectives encompassing academic and personal skills, for example, "students should be able to evaluate, classify and organise information into a suitable format for the application of decision-making techniques" (p. 326).
} 
identified as necessary by the accounting profession, than students in a traditional course. Barkman (1998) reports mixed student reaction on the use of live cases; some students indicate anecdotal appreciation at being exposed to real businesses, while others find the effort involved in completing the case too demanding. Neither Friedlan nor Barkman measured students' perceptions about the proposed benefits of the use of mini- or live cases, respectively.

A study that has measured students' perceptions about the benefits of case studies is by Hassall et al. (1998). Students were requested to indicate the extent to which a module, using only case studies, developed ten specified skills. The five most frequent "yes" responses, in descending order, were for negotiation skills, ability to work in a group, presentation skills, the ability to apply and integrate subject skills and knowledge and the ability to question assumptions and listen to arguments. When asked about the ability of case studies to develop knowledge, skills and personal qualities, 85 percent of the students agreed that case studies were the most appropriate teaching tool for developing knowledge; 90 percent agreed in respect of skills and 62 percent, personal qualities.

A similar study, by Weil et al. (2001), surveyed student perceptions on the usefulness of case studies for developing 31 thinking skills and other benefits identified from the literature (Campbell and Lewis, 1991; Wines et al., 1994; Kimmel, 1995; Hassall et al., 1998). Weil et $a l$. found that students perceived the use of case studies to enhance their learning by helping to develop several of the identified thinking skills and other benefits. The major perceived benefit of the use of case studies was the way in which they expose students to real-world complexity, particularly with respect to decision-making, followed by "several solutions to business problems". Weil et al. (2001) also classified the 31 benefits into 8 subscales. Four of the five highest benefits perceived by students fell into the "visualisation" subscale, which relates to the nexus between theory, practice and the real world. Students ranked the subscale "dealing with uncertainty", second after "visualisation". The "dealing with uncertainty" subscale contained questions relating to incomplete information, ambiguity in information and multiple possible solutions.

Weil et al. (2001) also compared students' perceptions by gender. Although the rankings of the benefits of case studies by gender are similar for males and females, the study found that males perceive the use of case studies to facilitate the development of critical thinking ability and pertinent questioning more than do females. Consistent with this lower ranking by female 
students of "pertinent questioning", which is a component of the "active participation" subscale, is their lower ranking of this subscale. Female students also ranked case studies' benefits for the development of interpretative skills and dealing with uncertainty and ambiguity lower than males.

In respect of prior academic performance, Weil et al. (2001) found that below-average students find case studies more beneficial for "applying theory to the real-world" than do above-average students. Below-average students also find case studies more useful for "applying knowledge", and for developing the ability to summarise information.

The results of the Hassall et al. (1998) and Weil et al. (2001) studies suggest that case studies, as perceived by students, do indeed provide learning benefits. The results of the latter study, however, suggest that lecturers considering the use of case studies need to reflect carefully on their reasons for using them and the relationship of this educational tool to the course objectives (Bonner, 1999), on the one hand, and the gender and capability profile of the class, on the other.

\subsection{The Increasing Trend Towards Competency-Based Professional Accounting Education}

The move towards a competency-based approach for professional accounting education started in the United States of America (USA) with the publication of the Bedford Report (American Accounting Association (AAA), 1986), titled "Future Accounting Education: Preparing for the Expanding Profession". The report considered numerous aspects of the accounting profession and accounting education in the USA, concluding that major changes were needed in accounting education to prepare accountants for an expanding and changing profession. A key educational recommendation in the report was for accountants to acquire, maintain and continuously enhance higher levels of competence to meet increasingly diverse demands for services (AAA, 1986). With respect to the teaching process, the report noted that "many accounting graduates do not know how to communicate, cannot reason logically, and have limited problem-solving ability" (AAA, 1986, p. 177). The report attributes these deficiencies primarily to the then predominant teaching method of lectures together with routine-problem solving, neither of which is conducive to creative thinking. The report recommends that in order to develop students' abilities to use knowledge analytically and in 
creative and innovative ways, teaching methods need to be supplemented by active learning techniques, such as discussions of concepts and the use of cases.

The recommendations of the Bedford Report were given added impetus by the release by the Big Eight ${ }^{4}$ accounting firms of a White Paper titled "Perspectives on Education: Capabilities for Success in the Accounting Profession" (Perspectives, 1989). Supporting the main theme of the Bedford Report (AAA 1986), the White Paper stated that "education for the accounting profession must produce graduates who have a broad array of skills and knowledge" (Perspectives, 1989, p. 5). The key skills enumerated by the firms were: (1) the ability to use critical thinking and creative problem-solving techniques on unstructured problems in diverse and unfamiliar settings, (2) an understanding of interpersonal and group dynamics, (3) the ability to communicate, both orally and in writing, and (4) the facility to manage change.

The academic community responded to the Bedford Committee Report and the Big Eight White Paper by establishing the Accounting Education Change Commission (AECC, 1990). The AECC specified that "accounting programs should prepare students to become professional accountants, not to be professional accountants at the time of entry to the profession" (AECC, 1990, p. 307). Focusing on "life-long learning", the AECC specifies three categories of skills required by successful accounting graduates - communication ${ }^{5}$, intellectual $^{6}$ and interpersonal ${ }^{7}$ (AECC, 1990). To enable students to acquire these skills and the strategies necessary to become life-long learners, the AECC encourages the use of appropriate instructional methods, stating that "students must become active participants in the learning process, not passive recipients of information. They should identify and solve unstructured problems... Working in groups should be encouraged" (AECC, 1990, p. 309).

More recently, the American Institute of Certified Public Accountants (AICPA) Core Competency Framework for Entry into the Accounting Profession (AICPA 1999) restated, as

\footnotetext{
${ }^{4}$ The Big Eight firms have since been reduced to the Big Four as a result of mergers.

${ }^{5}$ Examples of communication skills include "the ability to present, discuss, and defend views effectively through formal and informal, written and spoken language" (AECC, 1990, p. 311).

${ }^{6}$ Examples of intellectual skills include:

- "capacities for inquiry, abstract logical thinking, inductive and deductive reasoning and critical analysis", and

- ability to identify and solve unstructured problems in unfamiliar settings and to apply problemsolving skills in a consultative process" (AECC, 1990, p. 311).

${ }^{7}$ Examples of interpersonal skills include:

- "ability to work with others, particularly in groups, to influence them, to lead them, to organize and delegate tasks, to motivate and develop people, and to withstand and resolve conflict", and

- "ability to interact with culturally and intellectually diverse people" (AECC, 1990, p. 311 ).
} 
well as expanded ${ }^{8}$ the list of competencies required for professional accountants that were identified by the Big Eight (Perspectives, 1989) and the AECC (1990). The Framework also specifies additional teaching strategies, such as problem-based learning, by the use of cases, for the attainment of the competencies (AICPA, 1999). Further impetus to the development of competence-based approaches to the education and training of professional accountants has been provided by the recent release of an exposure draft discussion document by the IFAC (2001).

\subsection{The Development of the PAS/PCE 2 Programme}

In 1998, a new professional examination system for accountants, known as PAS/PCE 2, was introduced in New Zealand. The introduction of PAS/PCE 2 was the outcome of a review of its Admissions Policy, including the present examination system, commissioned by the New Zealand Society of Accountants ${ }^{9}$ (NZSA) in 1992.

PAS/PCE 2 replaced the Final Qualifying Examination (FQE), which had been in existence since 1989. Prior to the introduction of the FQE, a university graduate with a recognised degree (or equivalent), who met certain requirements, and three years of acceptable professional experience, could become an Associate Chartered Accountant (ACA) without further examination

The 1992 review was critical of the NZSA's admission requirements, concluding that they represented "a series of soft, undemanding hurdles" that, "if allowed to continue in its present form will condemn the New Zealand Society [of Accountants] to the second division of professional accounting bodies" (Marrian and Lothian, 1992, p. 26).

The Marrian and Lothian report recommended that more technical material be included in the FQE and that the examination should test professional competence. The NZSA, after careful consideration of the report, and appropriate consultation, developed a new Admission Policy (NZSA, 1994a). The Policy created an additional professional level - a chartered accountant (CA) - to be distinct from that of an ACA. To attain the level of a CA would require passing a further professional examination, to be known as Professional Competence Examination 2

\footnotetext{
8 Additional competencies identified include "professional demeanour, interaction and leadership" (AICPA 1999).

${ }^{9}$ The New Zealand Society of Accountants was renamed the Institute of Chartered Accountants of New Zealand in 1996.
} 
(PCE 2). The existing FQE examination, appropriately modified, was to be retained and renamed Professional Competence 1 (PCE $1^{10}$ ). By providing for two levels of chartered accountants, the NZSA envisaged accommodating both those not actively involved in providing accounting services (ACAs), as well as those involved in providing accounting services and who would require international recognition (CAs).

PCE 2 would comprise two four-hour examinations, covering five areas of advanced technical knowledge, namely, financial accounting, management accounting, auditing, taxation and finance. The emphasis in the examinations, however, would not be on technical content, but rather on the acquisition of certain specified competencies, that is, "on testing analytical and interpretive skills in a context similar to the 'real world' working environment, and the application of theoretical knowledge and professional attitudes to practical problems likely to be encountered in the business environment" (NZSA, 1994b, cited in Hay and Maltby, 1997, p. 173).

Candidates would only be eligible to sit PCE 2, however, if they had previously attended and passed a Professional Accounting School (PAS), which would develop and assess certain specified competencies, deemed to be required for admission to the profession. The Professional Accounting School comprises of three modules ${ }^{11}$, each of which is completed in sequence over three ten-week periods between February and October ${ }^{12}$.

Accounting graduates wishing to qualify as a chartered accountant, in addition to completing the PAS/PCE 2 programme, are required to complete a practical experience component with an approved training organisation (ATO), to facilitate the further development of competencies in the work place. Certification as a chartered accountant in New Zealand thus complies with the three components of the qualifying process identified by IEG \# 9 (IFAC 1996) of academic study, practical experience and tests of professional competence, via PAS/PCE 2.

\footnotetext{
${ }^{10} \mathrm{PCE} I$ would focus primarily on ethics and the authority and structure of the accounting profession.

"The three modules are:

Business Environment (covering strategy and aspects of the external business environment, which provide the context in which accounting decisions are made),

Compliance (covering external reporting, auditing and taxation), and

Financial Mamagement (covering management accounting, as well as financial management).

"For each module, candidates attended two workshops - one at the beginning and one at the end of each tenweck period. On achicving a $60 \%$ grade average or better in PAS, successful candidates sat the two case siudy unsed cxaminations, which comprise PCE 2. A candidate with a grade average of $60 \%$ or greater in PCT 2 passos PAS/PCE 2.
} 
The focus of the PAS programme is to use the resource materials ${ }^{13}$ as the context within which to develop specified competencies, rather than to develop a 'stand alone' body of knowledge. The identification and incorporation of competencies into the PAS/PCE 2 programme is based largely on a study by Birkett (1993). Birkett states that competency "relates to the way in which individual attributes (knowledge, skills and attitudes) are drawn on in performing tasks in particular work contexts (job performance) ${ }^{14}$.

Competencies $^{15}$, or individual attributes, as described by Birkett, consist of cognitive skills, knowledge and abilities, which are a function of the job requirements, and behavioural skills $^{16}$ or personal characteristics (principles, attitudes, values and motives) which are a function of an individual's personality. He developed a taxonomy of cognitive skills, comprising knowledge application skills (competent usage of specialised knowledge), analytical/constructive skills (problem identification and the development of solutions), and appreciative skills (evaluating complicated situations and making creative and complex judgements).

Using his taxonomy of skills, Birkett carried out a functional analysis (IFAC, 2001), identifying individual attributes (competencies) for five functional areas (auditing, external reporting, insolvency and reconstructions, management accounting, taxation and treasury). Birkett's analysis did not, however, identify attributes common to all five functional areas. In developing the PAS/PCE 2 programme, a generic approach was taken in terms of competency development, rather than one based on functional areas. This approach recognises the diversity of accounting roles of the candidates and the range in size of the organisations in which they are employed (IFAC, 1998). The generic competencies, which advanced Business Education Ltd. (ABEL) decided to use as the basis for competency development in the PAS/PCE 2 programme, are listed in Table 1.

\footnotetext{
${ }^{13}$ The Professional Competence Programme is administered by Advanced Business Education Ltd (ABEL), a wholly owned subsidiary of the Institute. The resource materials for the PAS/PCE 2 programme are prepared by UNITEC, New Zealand.

${ }^{14}$ Birkett's (1993) definition is similar to that of the IFAC (1993), namely, that "Competency is being able to perform a work role to a defined standard with reference to real working environments" (p. 13). Other possible definitions of competency relevant to this study are those by Spencer and Spencer (1993) and IFAC (2001).

${ }_{15}^{15}$ Also called "capabilities" in the IFAC (2001) exposure draft discussion paper.

${ }^{16}$ A consideration of these is beyond the scope of this study.
} 
Table 1

PAS/PCE 2 Competencies

Identify and solve business problems in the unstructured business environment

- Conceptualise a problem

- Solve problems - to identify, analyse and resolve issues

- Demonstrate a strategic perspective - see the macro as well as the micro perspective

Communicate orally and in writing

- Communicate effectively and appropriately in writing

- Express ideas articulately in an oral presentation and in a manner appropriate to the situation

Demonstrate ethical awareness

Research, analyse and synthesise information

- Ability to research and analyse data

Work in a team

- Work effectively as a team member

- Present a viewpoint, justify it and influence others' thinking

- Listen and empathise - put yourself in another's shoes

- Negotiate

- Resolve conflicts

- Undertake a leadership role

Integrate accounting sub-discipline knowledge

- Identifying what is important - to prioritise

- Integrate knowledge

Understand other business disciplines within an organisational context

- Evaluate situations from more than one perspective

It is noticeable from Table 1 that the competencies incorporated into the PAS/PCE 2 programme, with the exception of "Demonstrate ethical awareness", closely approximate the competencies specified by the Big Eight (Perspectives 1989) and AECC (1990) ${ }^{17}$. The PAS programme employs two main pedagogical techniques - study groups and case-based learning - to facilitate the development of the competencies. These teaching techniques, which are frequently used in conjunction with each other, are strongly recommended by both the AECC (1990) and the AICPA (1999) and are extensively documented in the literature with respect to their ability to develop students' competencies (Weil et al. 2001; Bonner 1999; Ravenscroft et al. 1999; Weil et al. 1999; Caldwell et al. 1996; Saudagaran 1996; Hite 1996; Knechel 1992; Campbell and Lewis 1991). The PAS/PCE 2 programme thus incorporates many of the principles proposed in the Bedford Report (AAA 1986), the White Paper (Perspectives 1989), the AECC (1990), the AICPA (1999) and the IFAC (2001), in particular, the competency-based approach and the extensive use of case studies and study groups.

${ }^{17}$ Ethical awareness subsequently features prominently as a core competency in AICPA (1999) and IFAC (1996 and 2001) publications. 
It is evident from the review of the literature that research measuring the perceived benefits of using case studies to develop competencies in professional accounting programmes is minimal or non-existent. This study aims to contribute to filling this gap in the literature by assessing student perceptions of the benefits of case studies and the association between the perceptions of the benefits of case studies and certain factors of candidates, such as, gender and first language. The methodology employed in conducting the research is described next.

\section{Research Methodology}

\subsection{Background to the Study}

The study was conducted with 518 PAS candidates, at workshops throughout New Zealand and Malaysia, in 2000. Many of the candidates may have experienced the case study approach in their prior academic studies. During the PAS programme, each of the six workshops would typically contain at least two case studies, on which the various workshop activities would be based. Most case studies were between ten and fifteen pages in length, comprising a narrative section and financial data, usually consisting of financial reports. Most of the cases were based on real companies, thus avoiding the criticism that cases frequently create oversimplified (Bonk and Smith, 1998) or unrealistic contexts (Stoneham, 1995). The cases were both issues and appraisals cases (Wines et al., 1994), requiring interpretational and decision-oriented approaches (Knechel, 1992). Specific questions, driven by competency development, were set for each case study. The case study presentations and submissions were assessed both on a content and presentation basis.

\subsection{Research Objective}

The primary objective of the study is to investigate the perceived usefulness of case studies for imparting/developing fifteen core competencies to prospective chartered accountants. As a complement to this main objective, the study also aims to observe and report on possible differences in perception across a number of homogenous groups such as age, work experience, gender, organisational type, etc. This line of enquiry is pursued on both a single competency basis, using fifteen important skills identified in the literature and by the 
Professional Accounting School, and on a sub-scale basis, using extracted components of the competencies, as obtained from a factor analysis of collected data.

\subsection{Instrument Design and Data Collection}

A questionnaire was designed for administration to the target population. The questionnaire was based on that used in a previous study (Weil et al., 2001), which examined student perceptions of the use of case studies in a Finance Honours programme.

Data for the study were obtained through the administration of the survey questionnaire to workshop candidates at the conclusion of the last workshop in 2000. The questionnaire was completed as part of a workshop activity in which candidates focused on their personal development. Five hundred and six of the 518 candidates attending this workshop in New Zealand and Malaysia completed the questionnaire.

The questionnaire consisted of eight questions, seven of which were relevant to the objective of this study. The first six questions, as in Rainsbury et al. (2001), requested demographic information in respect of student gender, age, equivalent full-time work experience, usage of English as a first language, the nature of the candidate's employer's core business and the number of staff employed by the employer.

The main part of the questionnaire contained questions about the use of case studies and study groups ${ }^{18}$ in the PAS programme ${ }^{19}$. To minimise variations in students' responses due to different interpretations of the term "case study," it was defined in the questionnaire as "an unstructured academic assignment, containing numerous issues, which requires information to be analysed and organised, in an attempt to evaluate and select from alternative courses of action"20. $^{20}$

\footnotetext{
${ }^{18}$ The use of study groups, which is surveyed by question 8 , is beyond the scope of this study and will be reported on separately.

${ }^{19}$ As this study focused solely on the PAS programme, candidates' perceptions of the PCE 2 examination were not investigated.

${ }^{20}$ This definition is adapted from those used by Easton (1992) and Wines et al. (1994).
} 
Question 7 consisted of two parts; Part I asked candidates to rate, on a Likert-like scale of 1 (not at all) to 5 (extensively), the extent to which the use of case studies in PAS help develop/improve the 15 competencies examined in the study. The competencies (see question 7, Part I, (a) to (o) in the Appendix), being skills and abilities purportedly developed through the use of case studies, were adapted primarily from Weil et al's. (2001) study, supplemented by several PAS/PCE 2 competencies (see Table 1). The list of competencies is not exhaustive, but includes the benefits of case studies most frequently cited in the literature (Campbell and Lewis, 1991; Knechel, 1992; Wines et al., 1994; Kimmel, 1995; Hassall et al., 1998). Respondents were asked to indicate the extent to which the use of case studies helped them in developing or improving each of the listed competencies.

The 15 competencies can be organised under three headings, namely, Communication skills, listing questions relating to various components of the communication process; Problem Solving skills, encompassing skills relating to data exploration, problem identification, problem elaboration, dealing with incomplete and/or ambiguous information and assessing and choosing between different alternatives; and Presentation skills, containing questions about the attributes required when making oral presentations. The classification of the 15 competencies into these three headings is presented in Table $2^{21}$.

Table 2

\section{The Categorisation of Competencies into Sub-Scales}

\begin{tabular}{|c|c|c|}
\hline \multicolumn{3}{|l|}{ Sub-scales of competencies } \\
\hline Communication skills & Problem solving skills & Presentation skills \\
\hline $\begin{array}{l}\text { Help to develop appropriate } \\
\text { questioning skills }\end{array}$ & $\begin{array}{l}\text { Develop your ability to distinguish between } \\
\text { cause and effect in an unstructured business } \\
\text { situation }\end{array}$ & $\begin{array}{l}\text { Help you to develop your } \\
\text { ability to present a } \\
\text { viewpoint }\end{array}$ \\
\hline $\begin{array}{l}\text { Help you to develop active } \\
\text { listening skills }\end{array}$ & $\begin{array}{l}\text { Improve your ability to identify information } \\
\text { relevant to a particular issue by distinguishing } \\
\text { the relevant from the irrelevant information }\end{array}$ & $\begin{array}{l}\text { Develop your ability to } \\
\text { express ideas articulately } \\
\text { in an oral presentation }\end{array}$ \\
\hline $\begin{array}{l}\text { Improve your ability to } \\
\text { communicate articulately and } \\
\text { in ways appropriate for a } \\
\text { given situation }\end{array}$ & $\begin{array}{l}\text { Develop your ability to consider alternate } \\
\text { solutions and apply judgement }\end{array}$ & $\begin{array}{l}\text { Develop your ability to } \\
\text { present a viewpoint, } \\
\text { justify it and influence } \\
\text { others' thinking }\end{array}$ \\
\hline \multirow{5}{*}{$\begin{array}{l}\text { Develop your ability to } \\
\text { communicate appropriately in } \\
\text { writing }\end{array}$} & $\begin{array}{l}\text { Improve your ability to evaluate a situation } \\
\text { from more than one perspective }\end{array}$ & \\
\hline & Help you to integrate your knowledge & \\
\hline & $\begin{array}{l}\text { Develop your ability to analyse and solve } \\
\text { problems }\end{array}$ & \\
\hline & $\begin{array}{l}\text { Improve your ability to identify, analyse and } \\
\text { solve a problem }\end{array}$ & \\
\hline & $\begin{array}{l}\text { Improve your ability to identify and resolve } \\
\text { issues }\end{array}$ & \\
\hline
\end{tabular}

${ }^{21}$ The categories of skills are not entirely mutually exclusive, as it is possible to classify some of the skills under more than one category. Where this is the case, skills are classified under the best-fit' subscale. 
Part II of Question 7 asked candidates to identify the competency, which they believed, benefited most from the use of case studies in PAS. The last question, number 8 , relates specifically to the use of study groups, the results of which are not reported in this paper. Relevant extracts from the questionnaire are attached as an Appendix to this paper.

\subsection{Demographic Details}

Of the 518 candidates enrolled for the programme, the 506 who completed the questionnaire represented a usable response rate of 97 per cent. Demographic details of respondents are presented in Table 3.

Table 3

Respondent Demographics

\begin{tabular}{|c|c|c|c|c|c|c|}
\hline \multirow{3}{*}{ Age of respondents } & \multicolumn{6}{|c|}{ Gender of respondents } \\
\hline & \multicolumn{2}{|c|}{ Male } & \multicolumn{2}{|l|}{ Female } & \multicolumn{2}{|l|}{ Total } \\
\hline & Count & Percent & Count & Percent $^{*}$ & Count & Percent* \\
\hline $20-24$ & 76 & 29.5 & 76 & 30.6 & 152 & 30.0 \\
\hline $25-29$ & 145 & 56.2 & 125 & 50.4 & 270 & 53.4 \\
\hline $30+$ & 37 & 14.3 & 47 & 19.0 & 84 & 16.6 \\
\hline Total & 258 & 100.0 & 248 & 100.0 & 506 & 100.0 \\
\hline \multicolumn{7}{|l|}{ Work Experience } \\
\hline Less than 5 years & 191 & 74.0 & 170 & 68.5 & 361 & 71.3 \\
\hline $5-9$ years & 40 & 15.5 & 42 & 16.9 & 82 & 16.2 \\
\hline $10-19$ years & 21 & 8.1 & 27 & 10.9 & 48 & 9.5 \\
\hline $20-29$ years & 5 & 1.9 & 5 & 1.9 & 10 & 2.0 \\
\hline More than 30 years & 1 & 0.4 & 4 & 1.6 & 5 & 1.0 \\
\hline Total & 258 & 100.0 & 248 & 100.0 & 506 & 100.0 \\
\hline \multicolumn{7}{|l|}{ Core Business } \\
\hline Chartered Accountancy ("Top five" firm) & 122 & 47.3 & 119 & 48.0 & 241 & 47.6 \\
\hline Chartered Accountancy (Other) & 77 & 29.8 & 78 & 31.5 & 155 & 30.6 \\
\hline Corporate & 28 & 10.9 & 23 & 9.3 & 51 & 10.1 \\
\hline Public Service/Local government & 24 & 9.3 & 20 & 8.1 & 44 & 8.7 \\
\hline Other (please specify) & 7 & 2.7 & 8 & 3.2 & 15 & 3.0 \\
\hline $\begin{array}{r}\text { Total } \\
\end{array}$ & 258 & 100.0 & 248 & 100.0 & 506 & 100.0 \\
\hline \multicolumn{7}{|l|}{ Organisation size $\mathrm{e}^{\#}$} \\
\hline Small & 108 & 41.9 & 100 & 40.3 & 208 & 41.1 \\
\hline \multirow[t]{2}{*}{ Big } & 150 & 58.1 & 148 & 59.7 & 298 & 58.9 \\
\hline & 258 & 100.0 & 248 & 100.0 & 506 & 100.0 \\
\hline \multicolumn{7}{|l|}{ First language } \\
\hline English & 229 & 88.8 & 191 & 77.0 & 420 & 83.0 \\
\hline Others & 29 & 11.2 & 57 & 23.0 & 86 & 17.0 \\
\hline Total & 258 & 100.0 & 248 & 100.0 & 506 & 100.0 \\
\hline
\end{tabular}

* Percentages do not add up to 100 due to rounding errors.

\# Size of respondent's organisation, measured by total number of employees - Small = fewer than 100 employees, while Big $=$ more than 100 employees 
Two hundred and fifty-eight $(51 \%)$ of the respondents are male, as compared to 248 females. About 53 per cent (270) of them are in the modal age range of $25-29$ years. Of these, 125 are female, while the remaining 145 are male. Thirty per cent of the candidates are aged between 20 and 24 , while $84(17 \%)$ candidates are above 30 years of age.

The majority of the respondents $(361$ or $71 \%$ ) have work experience of less than 5 years. One hundred and ninety-one of these are male, as compared to 170 females. Eighty-iwo and 48 of the respondents are in the 5-9 years and 10-11 years work experience range respectively, while fifteen respondents have worked for 20 or more years. Most of the respondents (396 or $78 \%$ ) are working in chartered accountancy firms, 241 for the "Big $5^{22}$ " firms and 155 for other firms. Fifty-one respondents work for corporate firms, 44 for public services/local government organisations, while the remaining 15 work for organisations in "Other" core business areas. Fifty-nine per cent of the respondents are in "big" organisations (defined as employing more than 100 employees) while the remaining 208 work for organisations with fewer than 100 employees.

\subsection{Data Analysis}

To achieve the stated objectives of this study, three stages of analysis were undertaken. First, to ascertain the degree of usefulness ascribed to each of the 15 skills, the aggregate mean usefulness was computed. These means, ranked in descending order of usefulness, are presented in Panel A of Table 4. The table also shows the level of agreement among the students, as measured by the standard deviation of their responses, on each measurement variable. Complementarily, the sample was disaggregated into the demographic groupings identified in Table 3. The results, for age, work experience, core business, organisational size and first language are cross-tabulated with gender in Panels B to G of Table 4 respectively.

The second stage of the analysis involved the reduction of the data collected on competencies into logical component sub-scales. Factor analysis was employed for this purpose, with the 15 competencies being rotated, using varimax (with Kaiser normalisation) rotation method. A summary of the rotation solution and component extraction process is reported in Table 7. Three component factors, or sub-scales of competencies, were extracted at this stage of the

\footnotetext{
22 "Big 5" firms are referred to as "Top five" chartered accountancy firms in the questionnaire. The "non-Big 5" category includes candidates from all other organisations.
} 
analysis. The three sub-scales discussed under Instrument design and data collection were thus confirmed by the factor analysis.

These three sub-scales are analysed further in the third and final stage of the analysis. This stage also involved substantive statistical tests across the homogeneously distinct demographic groupings identified in Table 3. The results of these analyses are presented in Tables 5-6 and 8-9 of this study.

\section{Results and Discussion}

The survey and statistical test results are discussed and presented in this section. The preliminary statistics are presented first, followed by substantive statistical tests and discussion. Due to the nature of the data, all tests were non-parametric. The results are discussed in the following order: first, preliminary statistics, including aggregate ranking of case studies' usefulness by respondents and ranking across distinctive groupings of respondents are discussed. Next, substantive statistical test results, both pre- and post-data reduction procedures, are discussed.

\subsection{Preliminary Statistics}

This section reports on candidates' aggregate rankings of case studies' usefulness, the variablity of responses and rankings across homogeneously-distinct groupings.

\subsection{Aggregate Ranking of Case Studies' Usefulness}

The results of the statistical analysis (Table 4) indicate that candidates perceive case studies to be of the greatest usc in improving their "ability to evaluate a situation from more than one perspective". This competency was ranked highest among the 15 examined in this study. Case studies were next most useful in developing candidates "ability to consider alternative solutions and apply judgement". This is perhaps not surprising, given the relationship between this competency and the "ability to evaluate a situation from more than one perspective", which was ranked highest. Next in descending order of usefulness is the development of candidates' "ability to analyse and solve problems", with a mean usefulness of 3.77. On the opposite end of the scale, candidates perceive that the three skills that 
benefited least from the use of case studies are their "ability to communicate appropriately in writing", development of "active listening skills" and development of "appropriate questioning skills". These received an aggregate score of $3.35,3.41$ and 3.44 respectively. These three competencies are critical to a high quality communication process, and the fact that candidates perceive case studies to be having relatively less impact on their development deserves some attention.

\subsection{Variability of Responses}

It is noteworthy that the mean perceptions of candidates on the usefulness of case studies for developing the 15 competencies lie within a relatively short range (3.35 to 3.89$)$. This outcome is not surprising, however, as these skills, and their development, were identified in the literature as being the primary benefits to be derived from the use of case studies (Campbell and Lewis, 1991; Knechel, 1992; Wines et al., 1994; Kimmel, 1995; Hassall et al., 1998). The outcome was investigated further using two statistical procedures. First, a Chisquare test was performed to measure the variability of candidates' response on each of the 15 competencies. The results of the test (reported in Table 4) are statistically significant for all competencies, indicating a satisfactory level of variability in respondents' perception. Secondly, a Binomial test procedure was conducted, dichotomising the candidates' responses at a cut-off point of 3, to gauge the strength of the respondents' perception of the usefulness of case studies beyond this specified cut-off point. The results of the test (Table 4) indicate significant difference of opinion beyond this point for all but three of the 15 competencies. The majority of these (11) are significant at the $1 \%$ level, while one of them is at the $5 \%$ level. This reinforces the earlier finding of satisfactory level of variability in candidates' perception.

\subsection{Ranking Across Homogeneously-Distinct Groupings}

A statistical summary across six demographic groupings - age, gender, work experience, organisation type, organisation size and English as first language - is presented in Panels $B-G$ of Table 4. 
Table 4

Ranking of Competencies by Positive Impact of Case Studies on their Development/Improvement

\begin{tabular}{|c|c|c|c|c|c|}
\hline \multicolumn{6}{|c|}{ Panel A: All candidates $(n=506)$} \\
\hline RANK & COMPETENCIES & MEAN & S.D. & $\begin{array}{l}\text { Chi-square } \\
\text { Test } \\
\text { Statistics }\end{array}$ & $\begin{array}{l}\text { Binomial } \\
\text { Test } \\
\text { Statistics }\end{array}$ \\
\hline 1 & $\begin{array}{l}\text { Improve your ability to evaluate a situation from } \\
\text { more than one perspective? }\end{array}$ & 3.89 & .67 & $385.78^{\mathrm{a}}$ & $.000^{\mathrm{a}}$ \\
\hline 2 & $\begin{array}{l}\text { Develop your ability to consider alternate solutions } \\
\text { and apply judgement? }\end{array}$ & 3.82 & .64 & $419.10^{\mathrm{a}}$ & $.000^{\mathrm{a}}$ \\
\hline 3 & $\begin{array}{l}\text { Develop your ability to analyse and solve } \\
\text { problems? }\end{array}$ & 3.77 & .69 & $590.088^{\mathrm{a}}$ & $.000^{\mathrm{a}}$ \\
\hline 4 & $\begin{array}{l}\text { Improve your ability to identify information } \\
\text { relevant to a particular issue by distinguishing the } \\
\text { relevant from the irrelevant information? }\end{array}$ & 3.76 & .64 & $434.08^{\mathrm{a}}$ & $.000^{\mathrm{a}}$ \\
\hline 5 & Help you to integrate your knowledge? & 3.74 & .72 & $500.48^{\mathrm{a}}$ & $.000^{\mathrm{a}}$ \\
\hline 6 & $\begin{array}{l}\text { Improve your ability to identify, analyse and solve a } \\
\text { problem? }\end{array}$ & 3.72 & .66 & $587.24^{\mathrm{a}}$ & $.000^{\mathrm{a}}$ \\
\hline 7 & $\begin{array}{l}\text { Develop your ability to express ideas articulately in } \\
\text { an oral presentation? }\end{array}$ & 3.71 & .81 & $404.71^{\mathrm{a}}$ & $.000^{\mathrm{a}}$ \\
\hline 8 & $\begin{array}{l}\text { Help you to develop your ability to present a } \\
\text { viewpoint? }\end{array}$ & 3.71 & .73 & $530.79^{\mathrm{a}}$ & $.000^{\mathrm{a}}$ \\
\hline 9 & Improve your ability to identify and resolve issues? & 3.66 & .70 & $577.83^{\mathrm{a}}$ & $.000^{\mathrm{a}}$ \\
\hline 10 & $\begin{array}{l}\text { Improve your ability to communicate articulately } \\
\text { and in ways appropriate for a given situation? }\end{array}$ & 3.58 & .73 & $486.10^{\mathrm{a}}$ & $.003^{\mathrm{a}}$ \\
\hline 11 & $\begin{array}{l}\text { Develop your ability to present a viewpoint, justify } \\
\text { it and influence others' thinking? }\end{array}$ & 3.56 & .73 & $467.61^{a}$ & $.032^{b}$ \\
\hline 12 & $\begin{array}{l}\text { Develop your ability to distinguish between cause } \\
\text { and effect in an unstructured business situation? }\end{array}$ & 3.44 & .66 & $548.31^{\mathrm{a}}$ & .325 \\
\hline 13 & Help to develop appropriate questioning skills? & 3.44 & .72 & $481.86^{\mathrm{a}}$ & .623 \\
\hline 14 & Help you to develop active listening skills? & 3.41 & .80 & $416.70^{\mathrm{a}}$ & .720 \\
\hline 15 & $\begin{array}{l}\text { Develop your ability to communicate appropriately } \\
\text { in writing? }\end{array}$ & 3.35 & .82 & $358.62^{\mathrm{a}}$ & $.004^{\mathrm{a}}$ \\
\hline
\end{tabular}

$a$ and $b$ indicate that differences are significant at the 1 and $5 \%$ levels respectively 


\begin{tabular}{|c|c|c|c|c|}
\hline \multicolumn{5}{|c|}{ Panel B: Gender-based ranking } \\
\hline \multirow{2}{*}{ RANK } & \multirow[b]{2}{*}{$\mathbf{M}$} & \multirow[t]{2}{*}{ COMPETENCIES } & \multicolumn{2}{|l|}{ MEAN (S.D.) } \\
\hline & & & FEMALE(F) & $\mathrm{MALE}(\mathrm{M})$ \\
\hline 1 & 1 & $\begin{array}{l}\text { Improve your ability to evaluate a situation from more than } \\
\text { one perspective? }\end{array}$ & $3.91(.66)$ & $3.86(.68)$ \\
\hline 2 & 2 & $\begin{array}{l}\text { Develop your ability to consider alternate solutions and apply } \\
\text { judgement? }\end{array}$ & $3.86(.59)$ & $3.78(.69)$ \\
\hline 3 & $5=$ & Develop your ability to analyse and solve problems? & $3.81(.65)$ & $3.73(.72)$ \\
\hline 4 & $5=$ & $\begin{array}{l}\text { Improve your ability to identify information relevant to a } \\
\text { particular issue by distinguishing the relevant from the } \\
\text { irrelevant information? }\end{array}$ & $3.79(.62)$ & $3.73(.66)$ \\
\hline 5 & 8 & Improve your ability to identify, analyse and solve a problem? & $3.74(.61)$ & $3.69(.71)$ \\
\hline 6 & $3=$ & Help you to integrate your knowledge? & $3.72(.67)$ & $3.75(.76)$ \\
\hline 7 & 10 & Improve your ability to identify and resolve issues? & $3.71(.65)$ & $3.62(.74)$ \\
\hline 8 & 7 & Help you to develop your ability to present a viewpoint? & $3.70(.71)$ & $3.71(.75)$ \\
\hline 9 & $3=$ & $\begin{array}{l}\text { Develop your ability to express ideas articulately in an oral } \\
\text { presentation? }\end{array}$ & $3.67(.74)$ & $3.75(.86)$ \\
\hline 10 & 11 & $\begin{array}{l}\text { Improve your ability to communicate articulately and in ways } \\
\text { appropriate for a given situation? }\end{array}$ & $3.58(.69)$ & $3.58(.77)$ \\
\hline 11 & 9 & $\begin{array}{l}\text { Develop your ability to present a viewpoint, justify it and } \\
\text { influence others' thinking? }\end{array}$ & $3.49(.70)$ & $3.64(.76)$ \\
\hline 12 & 13 & $\begin{array}{l}\text { Develop your ability to distinguish between cause and effect } \\
\text { in an unstructured business situation? }\end{array}$ & $3.42(.67)$ & $3.46(.66)$ \\
\hline 13 & 14 & Help you to develop active listening skills? & $3.41(.80)$ & $3.41(.80)$ \\
\hline 14 & 12 & Help to develop appropriate questioning skills? & $3.38(.71)$ & $3.49(.74)$ \\
\hline 15 & 15 & Develop your ability to communicate appropriately in writing? & $3.37(.77)$ & $3.33(.87)$ \\
\hline
\end{tabular}

$\boldsymbol{a}$ and $\boldsymbol{b}$ indicate that differences are significant at the 1 and 5\% levels respectively 


\begin{tabular}{|c|c|c|c|c|c|c|}
\hline \multicolumn{7}{|c|}{ Panel C: Age-based ranking } \\
\hline \multicolumn{2}{|c|}{ RANK } & \multirow[b]{2}{*}{$30+$} & \multirow[b]{2}{*}{ COMPETENCIES } & \multicolumn{3}{|c|}{$\operatorname{MEAN}\left(S_{0} \mathrm{D}.\right)$} \\
\hline $20-24$ & $25-29$ & & & $20-24$ & $25-29$ & $30+$ \\
\hline 1 & 1 & 1 & $\begin{array}{l}\text { Improve your ability to evaluate a situation from } \\
\text { more than one perspective? }\end{array}$ & $3.95(.62)$ & $3.81(.70)$ & $\begin{array}{l}4.01 \\
(.67)\end{array}$ \\
\hline 2 & 2 & 3 & $\begin{array}{l}\text { Develop your ability to consider alternate } \\
\text { solutions and apply judgement? }\end{array}$ & $3.86(.61)$ & $3.78(.66)$ & $\begin{array}{l}3.88 \\
(.65)\end{array}$ \\
\hline 3 & 9 & $5=$ & $\begin{array}{l}\text { Help you to develop your ability to present a } \\
\text { viewpoint? }\end{array}$ & $3.80(.76)$ & $3.62(.73)$ & $\begin{array}{l}3.81 \\
(.67)\end{array}$ \\
\hline 4 & $3=$ & $5=$ & $\begin{array}{l}\text { Improve your ability to identify information } \\
\text { relevant to a particular issue by distinguishing the } \\
\text { relevant from the irrelevant information? }\end{array}$ & $3.76(.63)$ & $3.75(.64)$ & $\begin{array}{l}3.81 \\
(.67)\end{array}$ \\
\hline 4 & 7 & 8 & $\begin{array}{l}\text { Develop your ability to express ideas articulately } \\
\text { in an oral presentation? }\end{array}$ & $3.76(.82)$ & $3.69(.79)$ & $\begin{array}{l}3.69 \\
(.83)\end{array}$ \\
\hline 6 & $3=$ & 4 & $\begin{array}{l}\text { Develop your ability to analyse and solve } \\
\text { problems? }\end{array}$ & $3.75(.68)$ & $3.75(.70)$ & $\begin{array}{l}3.86 \\
(.66)\end{array}$ \\
\hline 7 & 6 & 7 & $\begin{array}{l}\text { Improve your ability to identify, analyse and } \\
\text { solve a problem? }\end{array}$ & $3.70(.67)$ & $3.70(.67)$ & $\begin{array}{l}3.78 \\
(.66)\end{array}$ \\
\hline 8 & 8 & 8 & $\begin{array}{l}\text { Improve your ability to identify and resolve } \\
\text { issues? }\end{array}$ & $3.63(.71)$ & $3.67(.69)$ & $\begin{array}{l}3.69 \\
(.69)\end{array}$ \\
\hline 9 & $3=$ & 2 & Help you to integrate your knowledge? & $3.62(.75)$ & $3.75(.69)$ & $\begin{array}{l}3.90 \\
(.72)\end{array}$ \\
\hline $10=$ & 11 & 11 & $\begin{array}{l}\text { Improve your ability to communicate articulately } \\
\text { and in ways appropriate for a given situation? }\end{array}$ & $3.56(.71)$ & $3.58(.75)$ & $\begin{array}{l}3.60 \\
(.75)\end{array}$ \\
\hline $10=$ & 10 & 13 & $\begin{array}{l}\text { Develop your ability to present a viewpoint, } \\
\text { justify it and influence others' thinking? }\end{array}$ & $3.56(.82)$ & $3.61(.68)$ & $\begin{array}{l}3.42 \\
(.75)\end{array}$ \\
\hline 12 & 12 & 12 & Help to develop appropriate questioning skills? & $3.38(.71)$ & $3.44(.73)$ & $\begin{array}{l}3.50 \\
(.74)\end{array}$ \\
\hline 13 & 14 & 10 & $\begin{array}{l}\text { Develop your ability to distinguish between cause } \\
\text { and effect in an unstructured business situation? }\end{array}$ & $3.36(.65)$ & $3.43(.65)$ & $\begin{array}{l}3.61 \\
(.71)\end{array}$ \\
\hline 14 & 15 & 15 & $\begin{array}{l}\text { Develop your ability to communicate } \\
\text { appropriately in writing? }\end{array}$ & $3.35(.85)$ & $3.35(.81)$ & $\begin{array}{l}3.32 \\
(.82)\end{array}$ \\
\hline 15 & 12 & 14 & Help you to develop active listening skills? & $3.33(.78)$ & $3.44(.80)$ & $\begin{array}{l}3.41 \\
(.86)\end{array}$ \\
\hline
\end{tabular}

$a$ and $b$ indicate that differences are significant at the 1 and 5\% levels respectively 


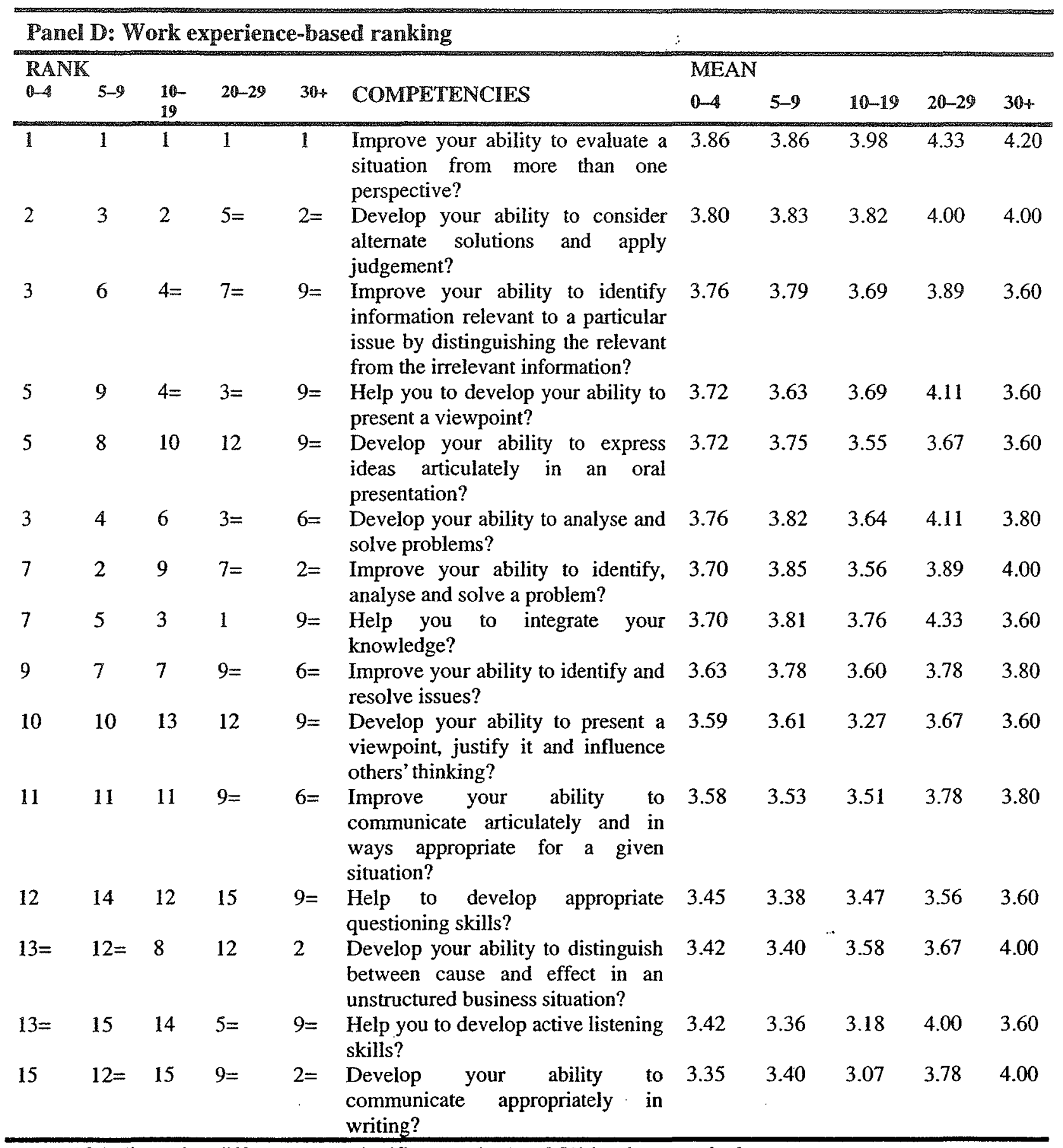

$a$ and $b$ indicate that differences are significant at the 1 and $5 \%$ levels respectively 


\begin{tabular}{|c|c|c|c|c|c|c|c|c|c|c|}
\hline \multicolumn{11}{|c|}{ Panel E: Core business-based ranking } \\
\hline \multirow{2}{*}{$\begin{array}{l}\text { RANK } \\
\text { Big5 }\end{array}$} & \multirow{2}{*}{$\mathrm{CA}$} & \multirow[b]{2}{*}{ Corp. } & \multirow[b]{2}{*}{ Public } & \multirow[b]{2}{*}{ Other } & \multirow[b]{2}{*}{ COMPETENCIES } & \multicolumn{2}{|c|}{ MEAN } & \multirow[b]{2}{*}{ Corp. } & \multirow[b]{2}{*}{ Public } & \multirow[b]{2}{*}{ Other } \\
\hline & & & & & & Big5 & $\mathrm{CA}$ & & & \\
\hline 1 & 2 & 1 & $2=$ & 1 & $\begin{array}{l}\text { Improve your ability to evaluate a } \\
\text { situation from more than one } \\
\text { perspective? }\end{array}$ & 3.93 & 3.86 & 3.82 & 3.81 & 3.87 \\
\hline 2 & 1 & 3 & $5=$ & 2 & $\begin{array}{l}\text { Develop your ability to consider } \\
\text { alternate solutions and apply } \\
\text { judgement? }\end{array}$ & 3.84 & 3.87 & 3.75 & 3.63 & 3.80 \\
\hline 3 & 9 & $7=$ & 9 & $3=$ & $\begin{array}{l}\text { Develop your ability to express } \\
\text { ideas articulately in an oral } \\
\text { presentation? }\end{array}$ & 3.81 & 3.62 & 3.63 & 3.55 & 3.73 \\
\hline 4 & 4 & $7=$ & $2=$ & $3=$ & $\begin{array}{l}\text { Develop your ability to analyse } \\
\text { and solve problems? }\end{array}$ & 3.80 & 3.75 & 3.63 & 3.81 & 3.73 \\
\hline 5 & 3 & 6 & 4 & $3=$ & $\begin{array}{l}\text { Improve your ability to identify } \\
\text { information relevant to a particular } \\
\text { issue by distinguishing the } \\
\text { relevant from the irrelevant } \\
\text { information? }\end{array}$ & 3.79 & 3.77 & 3.65 & 3.72 & 3.73 \\
\hline 6 & 8 & 2 & 1 & $10=$ & $\begin{array}{l}\text { Help you to integrate your } \\
\text { knowledge? }\end{array}$ & 3.78 & 3.65 & 3.78 & 3.86 & 3.53 \\
\hline 7 & 5 & 5 & $5=$ & 7 & $\begin{array}{l}\text { Improve your ability to identify, } \\
\text { analyse and solve a problem? }\end{array}$ & 3.77 & 3.68 & 3.67 & 3.63 & 3.64 \\
\hline 8 & 6 & 4 & $5=$ & $10=$ & $\begin{array}{l}\text { Help you to develop your ability } \\
\text { to present a viewpoint? }\end{array}$ & 3.76 & 3.66 & 3.71 & 3.63 & 3.53 \\
\hline 9 & 7 & 10 & 8 & 6 & $\begin{array}{l}\text { Improve your ability to identify } \\
\text { and resolve issues? }\end{array}$ & 3.72 & 3.66 & 3.51 & 3.56 & 3.67 \\
\hline $10=$ & 10 & 9 & 11 & $10=$ & $\begin{array}{l}\text { Improve your ability to } \\
\text { communicate articulately and in } \\
\text { ways appropriate for a given } \\
\text { situation? }\end{array}$ & 3.62 & 3.57 & 3.61 & 3.42 & 3.53 \\
\hline $10=$ & 11 & 10 & 10 & 13 & $\begin{array}{l}\text { Develop your ability to present a } \\
\text { viewpoint, justify it and influence } \\
\text { others' thinking? }\end{array}$ & 3.62 & 3.54 & 3.51 & 3.49 & 3.47 \\
\hline 12 & 12 & 14 & 14 & 15 & $\begin{array}{l}\text { Help to develop appropriate } \\
\text { questioning skills? }\end{array}$ & 3.49 & 3.44 & 3.37 & 3.23 & 3.33 \\
\hline 13 & 13 & 13 & 13 & $8=$ & $\begin{array}{l}\text { Develop your ability to distinguish } \\
\text { between cause and effect in an } \\
\text { unstructured business situation? }\end{array}$ & 3.47 & 3.43 & 3.41 & 3.29 & 3.60 \\
\hline 14 & 14 & 12 & 12 & $8=$ & $\begin{array}{l}\text { Help you to develop active } \\
\text { listening skills? }\end{array}$ & 3.42 & 3.35 & 3.49 & 3.37 & 360 \\
\hline 15 & 15 & 15 & 15 & 13 & $\begin{array}{ll}\text { Develop your ability } & \text { to } \\
\text { communicate appropriately } & \text { in } \\
\text { writing? } & \end{array}$ & 3.40 & 3.34 & 3.27 & 3.16 & 347 \\
\hline
\end{tabular}

$a$ and $b$ indicate that differences are significant at the 1 and $5 \%$ levels respectively 


\begin{tabular}{|c|c|c|c|c|}
\hline \multicolumn{5}{|c|}{ Panel F: Organisational size-based ranking } \\
\hline \multirow{2}{*}{$\begin{array}{l}\text { RANK } \\
\text { Small }\end{array}$} & \multirow[b]{2}{*}{ Big } & \multirow[b]{2}{*}{ COMPETENCIES } & \multirow{2}{*}{$\begin{array}{l}\text { MEAN } \\
\text { Srmall }\end{array}$} & \multirow[b]{2}{*}{ Big } \\
\hline & & & & \\
\hline 1 & 1 & $\begin{array}{l}\text { Improve your ability to evaluate a situation from more } \\
\text { than one perspective? }\end{array}$ & 3.91 & 3.87 \\
\hline 2 & 2 & $\begin{array}{l}\text { Develop your ability to consider alternate solutions and } \\
\text { apply judgement? }\end{array}$ & 3.86 & 3.79 \\
\hline 3 & 5 & $\begin{array}{l}\text { Improve your ability to identify information relevant to a } \\
\text { particular issue by distinguishing the relevant from the } \\
\text { irrelevant information? }\end{array}$ & 3.79 & 3.74 \\
\hline 4 & 3 & Develop your ability to analyse and solve problems? & 3.78 & 3.76 \\
\hline 5 & 8 & Help you to develop your ability to present a viewpoint? & 3.74 & 3.69 \\
\hline 6 & 6 & $\begin{array}{l}\text { Improve your ability to identify, analyse and solve a } \\
\text { problem? }\end{array}$ & 3.71 & 3.72 \\
\hline 7 & 3 & Help you to integrate your knowledge? & 3.70 & 3.76 \\
\hline 8 & 9 & Improve your ability to identify and resolve issues? & 3.69 & 3.65 \\
\hline 8 & 6 & $\begin{array}{l}\text { Develop your ability to express ideas articulately in an oral } \\
\text { presentation? }\end{array}$ & 3.69 & 3.72 \\
\hline 10 & 11 & $\begin{array}{l}\text { Improve your ability to communicate articulately and in } \\
\text { ways appropriate for a given situation? }\end{array}$ & 3.60 & 3.56 \\
\hline 11 & 10 & $\begin{array}{l}\text { Develop your ability to present a viewpoint, justify it and } \\
\text { influence others' thinking? }\end{array}$ & 3.56 & 3.57 \\
\hline $12=$ & 12 & $\begin{array}{l}\text { Develop your ability to distinguish between cause and } \\
\text { effect in an unstructured business situation? }\end{array}$ & 3.45 & 3.44 \\
\hline $12=$ & $13=$ & Help you to develop active listening skills? & 3.45 & 3.43 \\
\hline $12=$ & $13=$ & Help to develop appropriate questioning skills? & 3.45 & 3.43 \\
\hline 15 & 15 & $\begin{array}{l}\text { Develop your ability to communicate appropriately in } \\
\text { writing? }\end{array}$ & 3.34 & 3.35 \\
\hline
\end{tabular}

$a$ and $b$ indicate that differences are significant at the 1 and $5 \%$ levels respectively 


\begin{tabular}{|c|c|c|c|c|}
\hline \multicolumn{5}{|c|}{ Panel G: First language-based ranking } \\
\hline RANK & & & MEAN & \\
\hline Englissh & Other & COMPETENCIES & English & Other \\
\hline 1 & 1 & $\begin{array}{l}\text { Improve your ability to evaluate a situation from more } \\
\text { than one perspective? }\end{array}$ & 3.88 & 3.89 \\
\hline 2 & 2 & $\begin{array}{l}\text { Develop your ability to consider alternate solutions and } \\
\text { apply judgement? }\end{array}$ & 3.81 & 3.87 \\
\hline 3 & 3 & Develop your ability to analyse and solve problems? & 3.76 & 3.81 \\
\hline 4 & 4 & $\begin{array}{l}\text { Improve your ability to identify information relevant to } \\
\text { a particular issue by distinguishing the relevant from } \\
\text { the irrelevant information? }\end{array}$ & 3.75 & 3.80 \\
\hline 5 & 5 & Help you to integrate your knowledge? & 3.73 & 3.80 \\
\hline 6 & 6 & $\begin{array}{l}\text { Improve your ability to identify, analyse and solve a } \\
\text { problem? }\end{array}$ & 3.71 & 3.76 \\
\hline 7 & 7 & $\begin{array}{l}\text { Develop your ability to express ideas articulately in an } \\
\text { oral presentation? }\end{array}$ & 3.70 & 3.78 \\
\hline 8 & 8 & $\begin{array}{l}\text { Help you to develop your ability to present a } \\
\text { viewpoint? }\end{array}$ & 3.69 & 3.81 \\
\hline 9 & 9 & Improve your ability to identify and resolve issues? & 3.65 & 3.75 \\
\hline 10 & 10 & $\begin{array}{l}\text { Improve your ability to communicate articulately and } \\
\text { in ways appropriate for a given situation? }\end{array}$ & 3.54 & 3.78 \\
\hline 11 & 10 & $\begin{array}{l}\text { Develop your ability to present a viewpoint, justify it } \\
\text { and influence others' thinking? }\end{array}$ & 3.54 & 3.67 \\
\hline $12=$ & $12=$ & $\begin{array}{l}\text { Develop your ability to distinguish between cause and } \\
\text { effect in an unstructured business situation? }\end{array}$ & 3.40 & 3.64 \\
\hline $12=$ & $12=$ & Help to develop appropriate questioning skills? & 3.40 & 3.61 \\
\hline 14 & 14 & Help you to develop active listening skills? & 3.36 & 3.65 \\
\hline 15 & 15 & $\begin{array}{l}\text { Develop your ability to communicate appropriately in } \\
\text { writing? }\end{array}$ & 3.29 & 3.62 \\
\hline
\end{tabular}

$a$ and $b$ indicate that differences are significant at the 1 and $5 \%$ levels respectively

Female candidates perceive case studies to be of greater use to them in improving seven of the 15 competencies, as compared to their male counterparts. Some of these competencies are the ability to "identify information relevant to a particular issue by distinguishing the relevant from the irrelevant information", "consider alternate solutions" and "evaluate a situation from more than one perspective". Male candidates, on the other hand, rated the usefulness of case studies higher with respect to 6 of the 15 competencies, including developing/improving their "appropriate questioning skills", "ability to present a viewpoint" and "ability to express ideas articulately in an oral presentation".

Generally speaking, the $30+$ age group appears to have benefited the most from the use of case studies, given its mean rating of its usefulness across the 15 competencies examined in this study. This group particularly values the usefulness of case studies in developing/improving candidates' "ability to evaluate a situation from more than one perspective", "ability to integrate their knowledge" and "ability to consider alternate solutions and apply judgement". These competencies returned mean scores of $4.01,3.90$ and 3.88 
respectively. This outcome may be a product of the $30+$ age group members being in a better position to appreciate the usefulness of case studies, by virtue of their wider life experiences. Preliminary results for the other age groupings are mixed.

Another group that appears to place greater value on the benefits of case studies as a learning tool, relative to others, is that of candidates whose first language is not English. These candidates rank case studies as being more beneficial to them than their counterparts in developing/improving all but one of the 15 competencies. If confirmed through substantive testing, this result could have wide-ranging implications for the design of professional accounting programmes for non-native English-speaking candidates.

\subsection{Substantive Testing}

This section reports on differences in candidates' perceptions of the usefulness of case studies by different groups of respondents, both on individual and sub-scaled competency bases. The data reduction process is also discussed.

\subsection{Individual Competencies}

Non-parametric statistical tests were undertaken to investigate possible differences in the rating of the usefulness of case studies by the different groups of respondents. The MannWhitney $U$ test was applied to the gender and first language-based groups, while the KruskalWallis test was used to seek out possible differences in age-, work experience- and core business-based groupings. The results of the tests are reported in Tables 5 and 6 . 
Table 5

Monn-Whitney U Test of Differences in Candidates' Perception of the Positive Impact of Case Studies Method

\begin{tabular}{|c|c|c|c|c|}
\hline \multirow{2}{*}{ SKILLS } & \multirow{2}{*}{ Mean rank } & \multirow{2}{*}{\multicolumn{3}{|c|}{ Corrected for ties }} \\
\hline & & & & \\
\hline Develop your ability to present a viewpoint, & $\frac{\text { Female }^{*}}{232.97}$ & $\frac{\text { Male }^{2}}{268.53}$ & $\frac{2}{-3.011}$ & $\frac{M-W \text { sig. }(p)}{.003^{2}}$ \\
\hline justify it and influence others' thinking? & & & & \\
\hline $\begin{array}{l}\text { Help to develop appropriate questioning } \\
\text { skills? }\end{array}$ & 238.63 & 262.09 & -1.993 & $.046^{6}$ \\
\hline \multicolumn{5}{|l|}{ Panel B: First language-based } \\
\hline \multirow[b]{2}{*}{ SKILLS } & \multicolumn{2}{|l|}{ Mean rank } & \multicolumn{2}{|c|}{ Corrected for ties } \\
\hline & English & $\begin{array}{l}\text { Non- } \\
\text { English }\end{array}$ & $\mathbf{Z}$ & M-W sig. (p) \\
\hline $\begin{array}{l}\text { Develop your ability to distinguish between } \\
\text { cause and effect in an unstructured business } \\
\text { situation? }\end{array}$ & 241.52 & 291.31 & -3.222 & $.001^{2}$ \\
\hline $\begin{array}{l}\text { Develop your ability to communicate } \\
\text { appropriately in writing? }\end{array}$ & 241.07 & 296.52 & -3.464 & $.001^{2}$ \\
\hline $\begin{array}{l}\text { Help to develop appropriate questioning } \\
\text { skills? }\end{array}$ & 244.28 & 280.85 & -2.333 & $.020^{\mathrm{b}}$ \\
\hline Help you to develop active listening skills? & 241.63 & 291.36 & -3.131 & $.002^{2}$ \\
\hline $\begin{array}{l}\text { Improve your ability to communicate } \\
\text { articulately and in ways appropriate for a } \\
\text { given situation? }\end{array}$ & 244.17 & 284.41 & -2.569 & $.010^{\mathrm{b}}$ \\
\hline
\end{tabular}

$a$ and $b$ indicate that differences are significant at the 1 and $5 \%$ levels respectively.

Statistically significant differences were found between male and female candidates' perception of the usefulness of case studies in imparting or improving two competencies. Male candidates perceive case studies to be more useful in developing their "ability to present a viewpoint, justify it and influence others' thinking" (significant at the $1 \%$ level), and in helping "to develop appropriate questioning skills" (significant at the $5 \%$ level). The latter result is consistent with that of Weil et al. (2001).

Perhaps not surprising, but interestingly, candidates whose first language is not English perceive case studies to be more useful to them than English as first language candidates with regards to five competencies. Three of these (see Table 5, Panel B) are significant at the $1 \%$ level, while two are significant at the $5 \%$ level. Of particular significance is the fact that 4 of the 5 competencies are communication-related. Non-native English-speaking candidates perceive case studies to be of greater use to them in developing their "ability to communicate appropriately in writing", helping them "to develop appropriate questioning skills", assisting them "to develop active listening skills" and improving "their ability to communicate articulately and in ways appropriate for a given situation". In addition to these four communication-related areas, non-native English-speaking candidates also benefited more 
from the use of case studies in developing their "ability to distinguish between cause and effect in an unstructured business situation.

When analysed on an age basis, there were statistically significant differences in candidates' perception of the usefulness of case studies for imparting four of the competencies examined in this study. The four competencies, as presented in Panel A of Table 6 are the development of candidates "ability to distinguish between cause and effect in an unstructured business situation", the improvement of their "ability to evaluate a situation from more than one perspective", helping them to develop their "ability to present a viewpoint" and helping them to integrate their knowledge. Differences between the three age groups are significant at the $5 \%$ level for these competencies. For all four competencies, candidates above the age of thirty perceive case studies as being more useful than candidates from the other two age groups. Candidates in the 20-24 age group perceive cases to be of greater use to them in improving their ability to evaluate a situation from more than one perspective and in helping them to develop their ability to present a view point, than those in the 25-29 age group, while 25-29 year-olds place greater value on the usefulness of case studies for imparting the other two skills than 20-24 year-olds. 
Table 6

Kruskal-Wallis Test of Differences in Candidates' Perception of the Positive Impact of Case Studies Method

\begin{tabular}{|c|c|c|c|c|c|c|c|c|}
\hline \multicolumn{9}{|l|}{ Panel A: Age-based differences } \\
\hline \multirow[b]{2}{*}{ Competencies } & \multicolumn{3}{|c|}{ Mean rank for: } & \multicolumn{5}{|c|}{ Corrected for ties } \\
\hline & & \multicolumn{2}{|c|}{$25-29$} & $30+$ & $\chi^{2}$ & \\
\hline \multirow{2}{*}{$\begin{array}{l}\text { Develop your ability to distinguish } \\
\text { between cause and effect in an } \\
\text { unstructured business situation? } \\
\text { Improve your ability to evaluate a } \\
\text { situation from more than one } \\
\text { perspective? }\end{array}$} & 235.46 & 247.87 & \multicolumn{2}{|c|}{282.40} & 7.167 & \multicolumn{3}{|c|}{$.028^{\mathrm{b}}$} \\
\hline & 261.92 & \multicolumn{2}{|c|}{238.27} & 272.23 & 6.229 & \multicolumn{3}{|c|}{$.044^{\mathrm{b}}$} \\
\hline \multirow{2}{*}{$\begin{array}{l}\text { Help you to develop your ability to } \\
\text { present a viewpoint? } \\
\text { Help you to integrate your }\end{array}$} & 268.14 & 235.85 & \multicolumn{2}{|c|}{268.92} & 7.938 & \multicolumn{3}{|c|}{$.019^{b}$} \\
\hline & 231.68 & 251.03 & \multicolumn{2}{|c|}{282.21} & 8.106 & & \multicolumn{2}{|l|}{$.017^{\mathrm{b}}$} \\
\hline \multicolumn{9}{|c|}{ Panel B: Work Experience-based differences } \\
\hline \multirow[b]{2}{*}{ Competencies } & \multicolumn{3}{|c|}{ Mean rank for: } & & & \multicolumn{3}{|c|}{ Corrected for ties } \\
\hline & $0-4$ & $5-9$ & $10-19$ & $20-29$ & $\begin{array}{l}\text { More } \\
\text { than 30 }\end{array}$ & & $i^{2}$ & $\begin{array}{l}\text { Asymp. } \\
\text { sig. (p) }\end{array}$ \\
\hline $\begin{array}{l}\text { Improve your ability to evaluate a } \\
\text { situation from more than one } \\
\text { perspective? }\end{array}$ & 246.09 & 247.78 & 266.44 & 348.05 & 311.60 & & 391 & $.078^{\mathrm{c}}$ \\
\hline $\begin{array}{l}\text { Help you to develop your ability to } \\
\text { present a viewpoint? }\end{array}$ & 254.89 & 226.72 & 247.59 & 338.40 & 224.70 & & .015 & $.091^{\mathrm{c}}$ \\
\hline \multicolumn{9}{|l|}{$\begin{array}{l}\text { Help you to integrate your } \\
\text { knowledge? }\end{array}$} \\
\hline $\begin{array}{l}\text { Develop your ability to present a } \\
\text { viewpoint, justify it and influence } \\
\text { others' thinking? }\end{array}$ & 256.85 & 252.17 & 194.94 & 287.80 & 278.80 & & 0.343 & $.035^{\mathrm{b}}$ \\
\hline $\begin{array}{l}\text { Develop your ability to communicate } \\
\text { appropriately in writing? }\end{array}$ & 250.24 & 253.77 & 217.85 & 336.30 & 358.00 & & 0.148 & $.038^{\mathrm{b}}$ \\
\hline $\begin{array}{l}\text { Help you to develop active listening } \\
\text { skills? }\end{array}$ & 251.01 & 246.17 & 220.49 & 359.65 & 298.60 & & 899 & $.042^{b}$ \\
\hline \multicolumn{9}{|c|}{ Panel C: Core Business-based differences } \\
\hline \multirow[t]{2}{*}{ Competencies } & \multicolumn{3}{|c|}{ Mean rank for: } & & & & \multicolumn{2}{|c|}{$\begin{array}{l}\text { Corrected for } \\
\text { ties }\end{array}$} \\
\hline & (Big & Ather) & Corporate & $\begin{array}{l}\text { Public } \\
\text { / Local g }\end{array}$ & $\begin{array}{l}\text { sector } \\
\text { govt. }\end{array}$ & Other & $\chi^{2}$ & $\begin{array}{l}\text { Asymp. } \\
\text { sig. (p) }\end{array}$ \\
\hline $\begin{array}{l}\text { Develop your ability to express } 266 \\
\text { ideas articulately in an oral } \\
\text { presentation? }\end{array}$ & & 32.35 & 231.46 & 232.61 & & 260.03 & 8.373 & $.079^{c}$ \\
\hline
\end{tabular}

$b$ and $c$ indicate that differences are significant at the 5 and $10 \%$ levels respectively.

The "age effect" is indirectly but further confirmed in the result of analysis of work experience-based differences (Panel B of Table 6). Differences were found between the perception of candidates in different work experience groups with regards to six of the competencies investigated in this study. In addition to three of the four competencies for which significant differences were identified in age-group analysis above (the development of ability to distinguish between cause and effect in an unstructured business situation being the exception), statistically significant differences were also found between work experience 
groupings in their perception of case studies' impact on the development of their "ability to present a viewpoint, justify it and influence others' thinking", the development of their "ability to communicate appropriately in writing" and helping them "to develop active listening skills". With regards to five of the six skills, candidates in the 20-29 years work experience bracket perceive case studies to be more beneficial to them than candidates in all other brackets. Candidates with more than 30 years work experience perceive case studies to be more beneficial to them than all other groups in developing written communication ability. In essence, candidates with the work experience of 20 years and above place greater value on the usefulness of case studies for all six competencies than candidates with less work experience.

Only one area of significant difference was found between candidates on the basis of their type of core business. Candidates with Big 5 chartered accountancy (CA) firms perceive case studies to be of greater use to them in the development of their "ability to express ideas articulately in an oral presentation" than candidates in other types of organisations such as public sector/local government, corporate firms and non-big fire CA firms (results presented in Panel C of Table 6).

\subsection{Data Reduction}

Data were reduced by means of factor analysis. Upon rotation, three principal components, with Eigenvalues above 1, were extracted. These accounted for about $59 \%$ of the total variation. Eight of the competencies fell into the first principal component. These competencies are all of a problem-solving nature. They include the "ability to distinguish between cause and effect in an unstructured business situation", the "ability to identify information relevant to a particular issue by distinguishing the relevant from the irrelevant information" and the "ability to evaluate a situation from more than on perspective". Four competencies were extracted into the second principal component. They all relate to communication and include the "ability to communicate appropriately in writing", the development of appropriate questioning and listening skills and the "ability to communicate articulately and in ways appropriate for a given situation". The last three competencies extracted into a principal component made up of presentation-related skills such as "ability to present a view point", the "ability to express ideas articulately in an oral presentation" and the "ability to present a viewpoint, justify it and influence others' thinking". 
Table 7

Extraction of the Principal Components of Candidates' Perception of the Positive Impact of Case Studies Method Through Factor Analysis

\begin{tabular}{|c|c|c|c|c|c|c|c|c|c|}
\hline \multicolumn{10}{|c|}{ Panel A: Total Variance Explanation } \\
\hline \multirow[b]{2}{*}{$\begin{array}{l}\text { Component } \\
\text { Competency }\end{array}$} & \multicolumn{3}{|c|}{ Initial Eigenvalues (above 1) } & \multicolumn{3}{|c|}{$\begin{array}{l}\text { Extraction Sums of Squared } \\
\text { Loadings }\end{array}$} & \multirow{2}{*}{$\begin{array}{l}\text { Rotation } \\
\text { Loadings } \\
\text { Total }\end{array}$} & \multicolumn{2}{|c|}{ Sums of Squared } \\
\hline & Total & $\begin{array}{l}\% \text { of } \\
\text { Variance }\end{array}$ & $\begin{array}{l}\text { Cumulative } \\
\%\end{array}$ & Total & $\begin{array}{l}\text { \% of } \\
\text { Var. }\end{array}$ & Cum. \% & & $\begin{array}{l}\text { \% of } \\
\text { Var. }\end{array}$ & Cum. \% \\
\hline 1 & 6.397 & 42.645 & 42.645 & 6.397 & 42.645 & 42.645 & 3.874 & 25.823 & 25.823 \\
\hline 2 & 1.403 & 9.355 & 52.000 & 1.403 & 9.355 & 52.000 & 2.586 & 17.237 & 43.060 \\
\hline 3 & 1.019 & 6.796 & 58.796 & 1.019 & 6.796 & 58.796 & 2.360 & 15.736 & 58.796 \\
\hline \multicolumn{10}{|c|}{ Panel B: Rotated Component Matrix } \\
\hline \multirow{2}{*}{\multicolumn{2}{|c|}{ Competencies }} & & & & \multicolumn{2}{|c|}{ Component } & & & \\
\hline & & & & & & 1 & 2 & & 3 \\
\hline \multirow{2}{*}{\multicolumn{6}{|c|}{$\begin{array}{l}\text { Develop your ability to distinguish between cause and effect in an } \\
\text { unstructured business situation? } \\
\text { Improve your ability to identify information relevant to a } \\
\text { particular issue by distinguishing the relevant from the irrelevant } \\
\text { information? }\end{array}$}} & .616 & & & \\
\hline & & & & & & .679 & & & \\
\hline \multicolumn{6}{|c|}{$\begin{array}{l}\text { Develop your ability to consider alternate solutions and apply } \\
\text { judgement? }\end{array}$} & 682 & & & \\
\hline \multicolumn{6}{|c|}{$\begin{array}{l}\text { Improve your ability to evaluate a situation from more than one } \\
\text { perspective? }\end{array}$} & .696 & & & \\
\hline \multicolumn{6}{|c|}{ Help you to develop your ability to present a viewpoint? } & & & & 598 \\
\hline \multicolumn{6}{|c|}{ Help you to integrate your knowledge? } & .666 & & & \\
\hline \multicolumn{6}{|c|}{ Develop your ability to analyse and solve problems? } & .672 & & & \\
\hline \multicolumn{6}{|c|}{$\begin{array}{l}\text { Develop your ability to express ideas articulately in an oral } \\
\text { presentation? }\end{array}$} & & & & 828 \\
\hline \multicolumn{6}{|c|}{$\begin{array}{l}\text { Develop your ability to present a viewpoint, justify it and } \\
\text { influence others' thinking? }\end{array}$} & & & & .721 \\
\hline \multicolumn{6}{|c|}{ Improve your ability to identify, analyse and solve a problem? } & .637 & & & \\
\hline \multicolumn{6}{|c|}{ Develop your ability to communicate appropriately in writing? } & & .601 & & \\
\hline \multicolumn{6}{|c|}{ Improve your ability to identify and solve problems? } & .636 & & & \\
\hline \multirow{2}{*}{\multicolumn{6}{|c|}{$\begin{array}{l}\text { Help to develop appropriate questioning skills? } \\
\text { Help you to develop active listening skills? }\end{array}$}} & & .756 & & \\
\hline \multirow{2}{*}{\multicolumn{6}{|c|}{$\begin{array}{l}\text { Help you to develop active listening skills? } \\
\text { Improve your ability to communicate articulately and in ways } \\
\text { appropriate for a given situation? }\end{array}$}} & & .839 & & \\
\hline & & & & & & & .677 & & \\
\hline
\end{tabular}

\subsection{Principal Component Competencies (sub-scales)}

Finally, statistical tests were undertaken to determine possible differences in candidates' perception of the usefulness of case studies in imparting the three principal component skills of problem-solving, communication and presentation. The results of Mamn-Whitney $U$ test indicate statistically significant differences in the perception of English and non-English first language candidates with regards to the impact of case studies on their communication skills (see Table 8, Panel B). Non-English candidates perceive cases to be of much greater use to them in this area. Differences between the two groups are significant at the $1 \%$ level. 
Table \&

Mann-Whitney U Test of Differences in Candidates' Perception of the Positive Impact of Case Studies Method on Competency Components

\begin{tabular}{|c|c|c|c|c|}
\hline \multicolumn{5}{|c|}{ Panel $\mathrm{A}$ : Gender-based differences } \\
\hline \multirow[b]{2}{*}{ SKILLS } & \multicolumn{2}{|l|}{ Mean rank } & \multicolumn{2}{|c|}{ Corrected for ties } \\
\hline & Female* & Male $^{*}$ & $\mathrm{Z}$ & $M-W$ sig. (p) \\
\hline Problem-solving & 253.94 & 238.35 & -1.217 & .224 \\
\hline Communication & 237.79 & 253.92 & -1.259 & .208 \\
\hline Presentation & 235.48 & 256.14 & -1.613 & .107 \\
\hline \multicolumn{5}{|c|}{ Panel B: First language-based differences } \\
\hline \multirow[b]{2}{*}{ SKILILS } & Mean rank & \multicolumn{3}{|c|}{ Corrected for ties } \\
\hline & English & $\begin{array}{l}\text { Non- } \\
\text { English }\end{array}$ & $Z$ & M-W sig. (p) \\
\hline Problem-solving & 247.19 & 240.14 & -.413 & .680 \\
\hline Communication & 234.72 & 301.43 & -3.905 & $.000^{\mathrm{a}}$ \\
\hline Presentation & 245.27 & 249.58 & -.253 & .801 \\
\hline
\end{tabular}

$a$ indicates that differences are significant at the $1 \%$ level.

Age-based differences were also found in candidates' perception of the usefulness of case studies. Candidates aged 30 and above perceive case studies to be of greater use to them in developing problem-solving skills. The results of Kruskal-Wallis test of differences in candidates' perception were significant at the 5\% level (Panel A of Table 9).

Table 9

Kruskal-Wallis Test of Differences in Candidates' Perception of the Positive Impact of Case Studies Method on Competency Components

\begin{tabular}{|c|c|c|c|c|c|c|c|}
\hline \multicolumn{8}{|c|}{ Panel A: Age-based differences } \\
\hline \multirow[b]{2}{*}{ Competencies } & \multicolumn{4}{|c|}{ Mean rank for: } & \multicolumn{3}{|c|}{ Corrected for ties } \\
\hline & $20-24$ & $25-29$ & \multicolumn{2}{|l|}{$30+$} & & \multicolumn{2}{|c|}{ Asymp. sig. (p) } \\
\hline Problem-solving & 238.17 & 239.33 & \multicolumn{2}{|c|}{281.85} & & \multicolumn{2}{|c|}{$.045^{\mathrm{b}}$} \\
\hline Communication & 229.11 & 254.56 & \multicolumn{2}{|c|}{248.56} & & \multicolumn{2}{|l|}{.217} \\
\hline Presentation & 261.88 & 243.36 & \multicolumn{2}{|c|}{225.99} & & \multicolumn{2}{|l|}{.171} \\
\hline \multicolumn{8}{|c|}{ Panel B: Work Experience-based differences } \\
\hline \multirow[b]{2}{*}{ Competencies } & \multicolumn{3}{|c|}{ Mean rank for: } & & & \multicolumn{2}{|c|}{ Corrected for ties } \\
\hline & $0-4$ & $5-9$ & $10-19$ & $20-29$ & $\begin{array}{l}\text { More } \\
\text { than } 30\end{array}$ & $\chi^{2}$ & $\begin{array}{l}\text { Asymp. } \\
\text { sig. (p) }\end{array}$ \\
\hline Problem-solving & 238.33 & 257.57 & 261.70 & 321.90 & 306.30 & 5.875 & .209 \\
\hline Communication & 247.84 & 231.06 & 236.32 & 299.50 & 336.30 & 4.603 & .330 \\
\hline Presentation & 251.34 & 243.19 & 204.83 & 292.40 & 193.50 & 6.072 & .194 \\
\hline \multicolumn{8}{|c|}{ Panel C: Core Business-based differences } \\
\hline \multirow[b]{2}{*}{ Competencies } & \multicolumn{4}{|c|}{ Mean rank for: } & & \multicolumn{2}{|c|}{ Corrected for ties } \\
\hline & $\begin{array}{l}\text { CA (Big } 5 \\
\text { firm) }\end{array}$ & $\begin{array}{l}\text { CA } \\
\text { (other) }\end{array}$ & Corporate & $\begin{array}{l}\text { Public sector/ } \\
\text { Local govt. }\end{array}$ & Other & $\chi^{2}$ & $\begin{array}{l}\text { Asymp. Sig. } \\
\text { (p) }\end{array}$ \\
\hline Problem-solving & 249.39 & 248.74 & 233.96 & 237.62 & 227.89 & .925 & .921 \\
\hline Communication & 251.55 & 241.73 & 255.08 & 206.71 & 285.54 & 5.006 & .287 \\
\hline Presentation & 262.40 & 223.71 & 238.36 & 249.71 & 231.18 & 7.191 & .126 \\
\hline
\end{tabular}

$b$ indicates that differences are significant at the $5 \%$ level. 


\section{Summary and Conclusion}

The results of the study indicate that PAS candidates perceive case studies as being useful for developing the competencies specified by the programme. The candidates perceive the major benefit of the use of case studies to be in improving their ability to evaluate situations from more than one perspective and their ability to consider alternative solutions. This differs from the Weil et al. (2001) study, which found that students perceived case studies to be most useful in exposing them to real-world complexity. Cognisance should be taken, however, of the fact that in the Weil et al. (2001) study, the course objective was to familiarise students with real-world decision-making complexities, whereas in the current study, the use of case studies is designed to improve candidates' competencies. The six benefits perceived most highly by candidates fall into the 'problem-solving' subscale, with the next two most highly ranked benefits falling into the 'presentation' subscale.

Although the rankings of the benefits of case studies by gender are similar for males and females, some statistically significant differences are found in the study. Male candidates perceive case studies to be more useful in developing their "ability to present a viewpoint, justify it and influence others" thinking", and in helping "to develop appropriate questioning skills".

When considered on a language basis, candidates whose first language is not English perceive case studies to be more useful to them than English first-language candidates with respect to five competencies. It is noteworthy that 4 of the 5 competencies are communication-related. Non-native English-speaking candidates perceive case studies to be of greater use to them in developing their "ability to communicate appropriately in writing", helping them "to develop appropriate questioning skills", helping them "develop active listening skills" and improving "their ability to communicate articulately and in ways appropriate for a given situation." In respect of problem-solving skills, non-native Englishspeaking candidates benefited more than native English speakers from the use of case studies in developing their "ability to distinguish between cause and effect in an unstructured business situation".

Four statistically significant differences in candidates' perception of the usefulness of case studies for imparting competencies were found in the age-based analyses. The competencies are the development of candidats" "ability to distinguish between cause and effect in an 
unstructured business situation", the improvement of their "ability to evaluate a situation from more than one perspective", helping them to develop their "ability to present a viewpoint" and helping them to "integrate their knowledge". For all four competencies, candidates above the age of thirty perceive case studies as being more useful than candidates from the other two age groups.

The "age effect" is confirmed in the analysis of work experience-based differences, with differences found between the perception of candidates in different work experience groups for six of the competencies investigated in this study. In addition to three of the four competencies for which significant differences were identified in the age-group analysis, statistically significant differences were also found between work experience groupings in their perception of case studies' impact on the development of their "ability to present a viewpoint, justify it and influence others' thinking", the development of their "ability to communicate appropriately in writing" and helping them "to develop active listening skills". Candidates with work experience of 20 years and above effectively place greater value on the usefulness of case studies for all six competencies than candidates with less work experience.

One area of significant difference was found between candidates on the basis of their type of core business. Candidates with Big 5 chartered accountancy (CA) firms perceive case studies to be of greater use to them in the development of their "ability to express ideas articulately in an oral presentation" than candidates in other types of organisations such as public sector/local government, corporate firms and non-big five CA firms.

When candidates' perceptions are analysed according to the subscales of problem-solving, communication and presentation, statistically significant differences are found in the perception of English and non-English first language candidates with regards to the impact of case studies on their communication skills. Non-English candidates perceive cases to be of much greater use to them in this area.

Significant age-based differences are also found in candidates' perception of the usefulness of case studies. Candidates aged 30 and above perceive case studies to be of greater use to them in developing problem-solving skills.

The results of this study provide useful information to the ICANZ in its continuing development of the PAS programme. In particular, the differences in perception between the 
genders and native versus non-native English speakers will need to be considered carefully. It is possible that the noted gaps with respect to gender are the results of previously documented differences in the perceptions of the identified groups of candidates. Females, when compared to their male counterparts, have been reported as being more likely to understate their abilities (Rainsbury, Hodges, Sutherland, Barrow 1998; Strebler 1997; Stybel and Peabody 1998). Whatever improvement is made to the programme as a result of the findings of this study will be of great benefit to future candidates in their competency development. Other professional accounting bodies with similar programmes may also benefit by reviewing the results of this study. The results, however, should be interpreted with caution, given that each programme of this nature is unique and needs to be treated as such. Hence, future studies may consider replicating this study using data collected on other similar programmes. The results of such studies may then be compared, possibly across national boundaries, to enrich our existing knowledge in the dynamic field of international accounting education.

\section{Suggestions for Further Research}

There are possible limitations associated with the current study. For example, it is noteworthy that the mean perception of candidates on the usefulness of case studies for developing the 15 competencies lie within a relatively short range, all being above the midpoint of the response scale. This suggests that the case method is capable of developing every competency included in the study - a finding that confirms the benefits of case studies propounded in the literature. Given, however, that all of the survey respondents were soon to write the PCE 2 examination, it could be argued that their responses were inflated to provide the type of feedback that ABEL would seek. Mitigating against this proposition is the fact that even though the responses cluster around the high end of the usefulness scale, a satisfactory level of variability in respondents' perception was observed by statistical testing. Future researchers may examine this phenomenon more intensively by designing studies that distinguish more clearly between skills on the high- and low-benefit ends of the scale.

Two findings of the study stand out as deserving of consideration for further research. One is the suggestion that non-native English speakers benefit more from the use of case studies than native-English speaking candidates. The other finding that can benefit from further study, is that females showed less favorable perceptions towards the use of case studies than 
males. Whether attributable to learning style differences, study group dynamics and/or other factors, further information is needed.

This study has not examined the impact of culture and learning style preferences (Auyeung and Sands, 1996; Fatt, 1995) on student perceptions about the benefits of case studies. Such a study may be particularly useful in the light of the results obtained for non-native English speakers. It has also not examined whether, and the extent to which, the use of case studies in the PAS programme has facilitated the development of professional competencies. This could be done by expanding this study to include measures of pre- and post-PAS perceptions of competencies, permitting conclusions to be drawn about the impact of case studies on competency development. These are topics for future researchers to consider. 


\section{References}

Accounting Education Change Commission (AECC) (1990). Objectives of education for accountants: Position Statement No. 1. Issues in Accounting Education, 5(2), 307-312.

Advanced Business Education Ltd (ABEL) (1999). Professional Accounting School and Professional Competence Examination 2, 2000 Programme. Christchurch.

American Accounting Association (AAA), Committee on the Future Structure, Content and Scope of Accounting Education (the Bedford Committee) (1986). Future Accounting Education: Preparing for the Expanding Profession. Issues in Accounting Education, I(1), 168-195.

American Institute of Certified Public Accountants (AICPA) (1999). Core Competency Framework for Entry into the Accounting Profession. New York, NY: AICPA

Auyeung, P., and Sands, J. (1996). A cross cultural study of the learning style of accounting students. Accounting and Finance, 36, 261-274.

Barkman, A. I. (1998). Teaching and Educational Note: The use of live cases in the accounting information systems course. Journal of Accounting Education, 16(3/4), 517 524 .

Birkett, W. P. (1993). Competency Based Standards for Professional Accountants in Australia and New Zealand. Sydney: Institute of Chartered Accountants in Australia and the New Zealand Society of Accountants.

Bonner, S. E. (1999). Choosing teaching methods based on learning objectives: an integrative framework. Issues in Accounting Education, 14(1), 11-39.

Bonk, C. J., and Smith, G. S. (1998). Alternative instructional strategies for creative and critical thinking in the accounting curriculum. Journal of Accounting Education, 16(2), 261-293

Caldwell. M. B. Weishar. J. and G. W. Glezen (1996). The Effect of Cooperative Learning on Student Perceptions of Accounting in the Principles Courses. Journal of Accounting Education, 14(1), 17-36.

Campbell, J. E., and Lewis, W. F. (1991). Using Cases in Accounting Classes, Issues in Accounting Education, 6(2), 276-283.

Easton, G. (1992). Learning From Case Studies. Hempstead: Prentice-Hall.

Fatt, J. P. T. (1995). Learning Styles in Accounting Education, Asian Review of Accounting, $3(1), 25-58$.

Friedlan, J. M. (1995). The effects of different teaching approaches on students' perceptions of the skills needed for success in accounting courses and by practicing accountants, Issues in Accounting Education, 10(1), 47-63. 
Fulmer, W. E. (1992). Using cases in management development programmes, Journal of Management Development, 11(3), 33-37.

Gobeil, J. and Phillips, F. (2001). Relating Case Presentation Style and Level of Student Knowldege to Fact Acquisition and Application in Accounting Case Analyses, Issues in Accounting Education, 16(2), 205-222.

Hassall, T., Lewis, S. and Broadbent, M. (1998). Teaching and learning using case studies: a teaching note, Accounting Education, 7(4), 325-334.

Hay, D. and Maltby, H. (1997). A New Approach to Accounting Examinations: the Final Qualifying Examination in New Zealand. Journal of Accounting Education, 15(2), 169. 179.

Hite. P. A. (1996). An Experimental Study of the Effectiveness of Group Exams in an Individual Income Tax Class. Issues in Accounting Education, 11(1), 61-75.

International Federation of Accountants (IFAC) (1996). Prequalification Education, Assessment of Professional Competence and Experience Requirements of Professional Accountants. International Education Guideline \# 9.

International Federation of Accountants (IFAC) (1998). Competence-based Approaches to the Professional Preparation of Accountants. Discussion Paper.

International Federation of Accountants (IFAC) (2001). Competence-Based Approaches to the Preparation and Work of Professional Accountants. Exposure Draft Discussion Paper.

Johnstone, K. M. and Biggs, S. F. (1998). Problem-based learning: introduction, analysis, and accounting curricula implications, Journal of Accounting Education, 16(3/4), 407-427.

Kimmel, P. A. (1995). Framework for Incorporating Critical Thinking into Accounting Education. Journal of Accounting Education. 13(3), 299-318

Knechel, W. R. (1992). Using the Case method in Accounting Instruction, Issues in Accounting Education, (Fall), 205-217.

Marrian, N. and Lothian, I. (1992). New Zealand Society of Accountants International Review of Admission Policy. Wellington: NZSA.

New Zealand Society of Accountants (NZSA) (1994a). 1995 Information Book for the Final Qualifying Examination. Wellington: NZ.SA.

New Zealand Society of Accountants (NZSA) (1994b). Admissions Policy. Wellington: NZSA.

Perspectives on Education: Capabilities for Success in the Accounting Profession (The White Paper) (1989) New York: Arthur Andersen \& Co., Arthur Young, Coopers \& Lybrand, Deloitte Haskins \& Sells, Ernst \& Whinney, Peat Marwick Main \& Co., Price Waterhouse, and Touche Ross. 
Rainsbury, E, Hodges, D., Sutherland, J. and Barrow, M. (1998). Academic, Employer and Student Collaborative Assessment in a Work-based Co-operative Education Course. Assessment and Evaluation in Higher Education, 23(3), 313-324.

Rainsbury, E., Weil, S. and Oyelere, P. (2001). A Critical Evaluation of Competency Development in a Professional Accounting Programme. Discussion Paper No. 95, Commerce Division, Lincoln University, New Zealand.

Ravenscroft. S. P., Buckless. F. A. and Hassall, T. (1999). Cooperative Learning - a Literature Guide. Accounting Education, 8(2): 163-176.

Saudagaran, S. M. (1996). The First Course in Accounting: An Innovative Approach, Issues in Accounting Education, 11(1), 83-94.

Schwartz, P. L. and Heath, C. J. (1994). Students' Perceptions of Course Outcomes and Learning Styles in Case-based Courses in a Traditional Medical School, Academic Medicine: Journal of the Association of American Medical Colleges, 69(6), 507.

Shapiro, B. P. (1984). Hints for Case Teaching. Boston, MA: Harvard Business School Publishing Division.

Spencer, L. and S. Spencer (1993). Competence at Work. New York: Wiley \& Sons.

Stoneham, P. (1995). For and Against the Case Method, European Management Journal, 13(2), 230-232.

Strebler, M. (1997). Soft Skills and Hard Questions, People Management, 3(11), 20-24

Stybel, L.J., and Peabody, M. (1998). Increasing the Future Potential of Women HR Executives, Compensation and Benefits Management, 14, 4.

Weil, S., Laswad, F., Frampton, C. and Radford, J. (1999). Cultural and Other Influences on Student Perceptions of the Use of case Studies and Study Groups in Management Accounting. Discussion Paper No. 62, Commerce Division, Lincoln University, New Zealand.

Weil, S., Oyelere, P., Yeoh, J. and Firer, C. (2001). A Study of Students' Perceptions of the Usefulness of Case Studies for the Development of Finance and Accounting-related Skills and Knowledge, Accounting Education, 10, 123-146.

Wines, G., Carnegie, G., Boyce, G. and Gibson, R. (1994). Using Case Studies in the Teaching of Accounting. Deakin University, Victoria: Australian Society of Certified Practising Accountants. 


\section{Appendix}

Extract from survey questionnaire: The usefulness of case studies for learning.

\section{Professional Accounting School Candidate Survey}

\section{Questionnaire}

Personal Profile

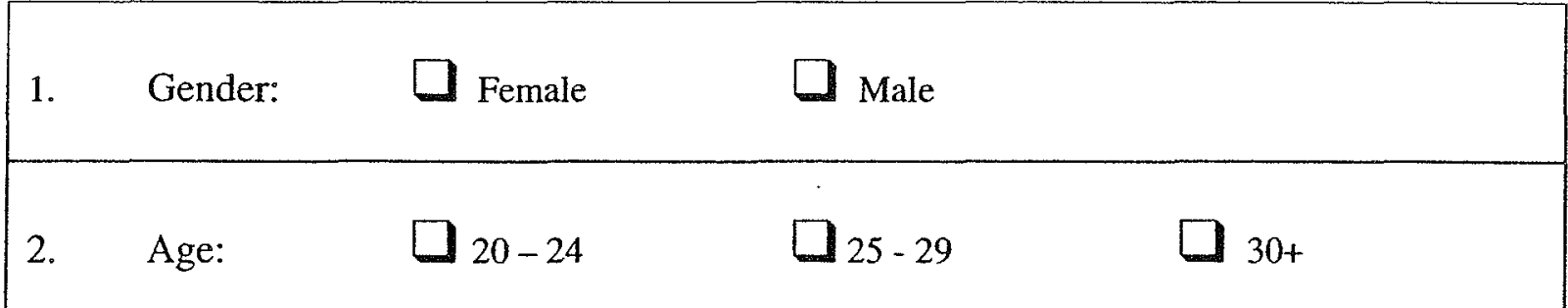

3. How many years of equivalent* full-time work experience have you completed since leaving high school?

$$
\text { years }
$$

* equivalent includes all full-time employment, irrespective of duration

4. Is English your first language?
$\square$ Yes
No

5. Please indicate the total number of employees in your organisation:

Fewer than $100 \quad \square$ More than 100

6. Please indicate the nature of your organisation's core business:
$\square$ Chartered Accountancy ("Top five" firm)
$\square$ Chartered Accountancy (Other)
$\square$ Corporate
$\square$ Public Service/Local government
$\square$ Other (please specify)

(Please Turn over) 
7. The following questions relate to your opinions about the usefulness of case studies in developing certain PAS competencies. In answering the questions, please ignore the impact that the group process (that is, working in study groups) might have had on your perceptions. This part of the questionnaire is concerned only with assessing your opinions about the usefulness of the case study approach in developing PAS competencies.

For the purpose of this survey, a case study is defined in this questionnaire as:

an unstructured academic assignment, containing numerous issues, which requires information to be analysed and organised, in an attempt to evaluate and select from alternative courses of action

\section{PART I:}

We would like your opinion on each of the following statements. Please choose a number on the following scale to indicate the strength of your preference for each question and encircle that number on the scale next to the question.

The rating scale relates to the question, "To what extent did the use of case studies in PAS...." help you to develop the PAS competencies.

Rating Scale:

$1 \quad$ Not at all

2

3 Moderate

4

5 Extensively

(Please circle the appropriate number for each question) 


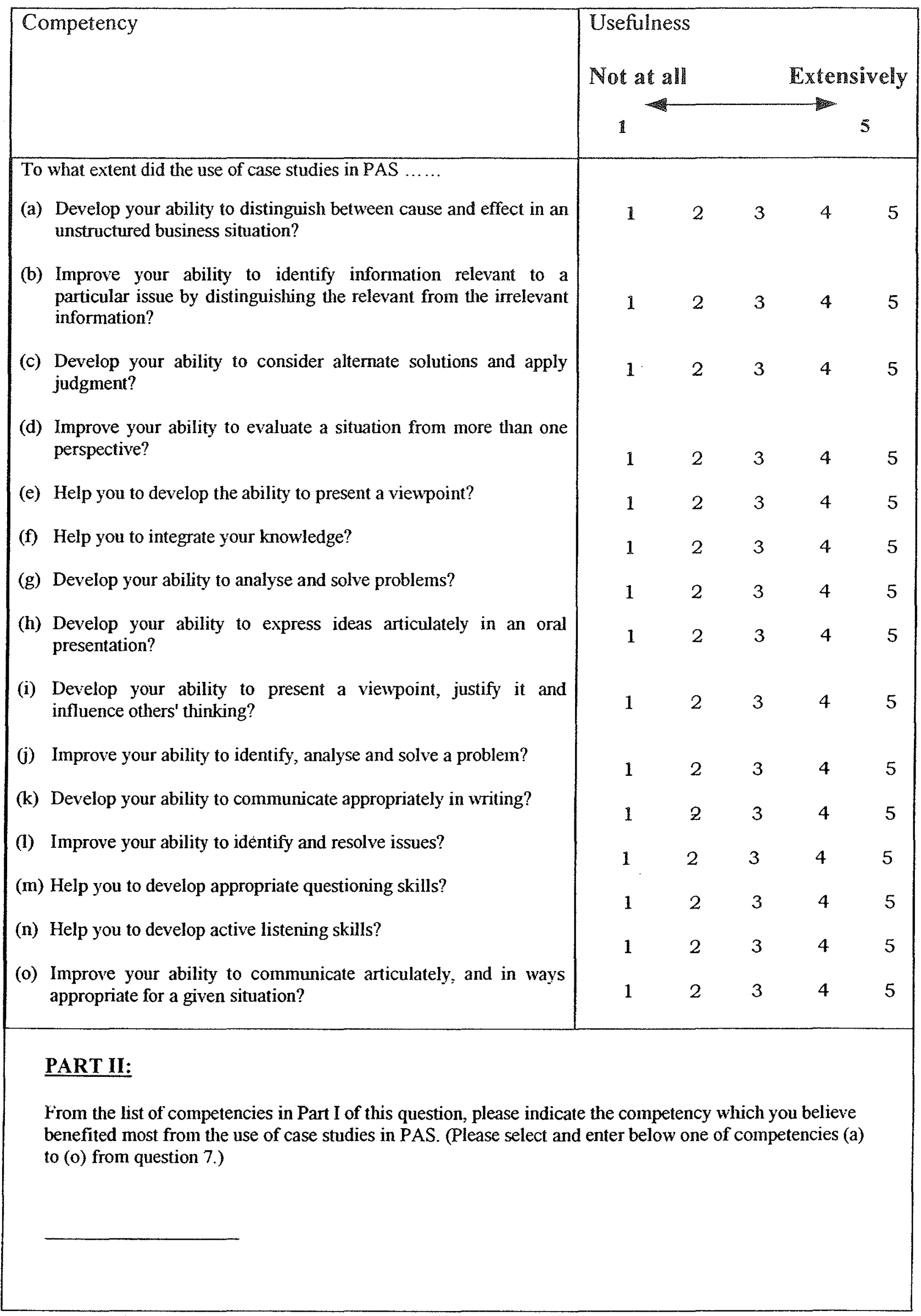

